öz

Sanayi-î Nefise Mektebi Âlisi 1927 yılında Fındıklı'daki Cemile Sultan Sarayı'na taşınarak kuruluşundan beri ilk kez yerleşik düzene geçmiştir. 1948 yılındaki yangın ile Akademi'nin kurmaya çalıştığı düzen bir süreliğine bozulmuştur. 1953 yılında yenilenen Akademi binası, saray yapısının planlama ilkelerini modern mimarlık ilkeleri ile birleştirmiştir.

Bu makaleye konu olan konferans salonu, binanın saray döneminde üst sofasıdır. 1954 yılı yenilemesinde aynı yerde benzer bir anlayışla sergi ve toplantı amaçlı bir salon planlanır. 1960'lı yıllarda salon, yeniden projelendirilerek çok amaçlı kullanıma yönelik esnek bir kullanım kazanır. Mekân ihtiyaçları, derslik sorunları ve bahçeye yapılan yeni toplantı salonunun etkisiyle konferans salonu giderek küçülmeye ve kurum içindeki önemini yitirmeye başlar.

Bu makale, konferans salonunun yıllar içindeki mekânsal değişimini, Akademi ortamı üzerinden aktarmaya çalışmaktadır.

Abstract

Cemile and Munire Sultans twin palaces was build for Sultan Abdulmecid's daughters at 1860 in Findiklt after which was used as Ottoman State assembly building. In 1927 School of Fine Arts moved to Cemile Sultan's Palace. This comfort would continue to 1948, until an unexpected fire, Academy's efforts for setting up an order halted for a time.

The Conference Hall which is the subject of this paper is in the upper level sofa of the former palace. After the fire, building was reconstructed in 1953 by S.H. Eldem and M.A. Handan. The new conference hall planned in the same place, as a manner similar hall, formally as a sofa for exhibitions and meetings. Influence of social and cultural environment of the Academy in the 1960s, a flexible solution for use in multipurpose hall are projected by U. Izzi and E. Suher. Later in the space needs, classroom problems and, with the effect of the new auditorium in the site, the conference hall begins smaller and loses importance in the Academy.

This paper aims to document the spatial change of the Conference Hall dating from 1927 to the present day with social and cultural environment of the Academy. Anahtar kelimeler:

Cemile Sultan Sarayı, Sanayi-î Nefise Mektebi Âlisi, Güzel Sanatlar Akademisi, Konferans Salonu, Sedad Hakkı Eldem, Mehmet Ali Handan, Utarit İzgi, Sofa, Hafif duvar, Bölme duvarı.

Keywords:

Cemile Sultan Palace, Sanayi-^ Nefise Mektebi Âlisi, Fine Arts Academy in Istanbul, Conference Hall, Sedad Hakkı Eldem, Mehmet Ali Handan, Utarit İzi, Sofa, light wall, separation.

\title{
Konferans Salonu: Sanayi-î Nefise Mektebi'nden Üniversiteye Bir Mekânın Tasarım ve Değişimi
}

2011 yılı Eylül ayında, Osman Hamdi Holü'nün Kabataş yönündeki aydınlığ kapatan çelik-beton karışımı yapı, binaya verdiği statik sorun nedeniyle, binadan ayıklandı, söküldü... 90'lı yıllarda, boşluğun mekân sıkıntısına bir çözüm olarak görülmesi ve kapatılmasının ardından 1şı ̆̆ı kısılan koridorlar, her bir katın duvarları ve döşemeleri söküldükçe yavaş yavaş eski aydınlığına kavuşmaya başladı.' Tanıklığımızda gerçekleşen bu olay, hem mekânı yaşayanların 'belleğini tazelemek' hem de kurumun: Mimar Sinan Güzel Sanatlar Üniversitesi'nin belleğine bir not düşmek için küçük bir araştırma yapılmasına, dolayısıyla bu yazıya vesile oldu.

1985 yılında, benden önce ve sonra 90’lı yılların ortasına dek $^{2}$, o zamanki adıyla Mimar Sinan Üniversitesi’ni kazanarak, kapısından giren her genç gibi, beni de derinden etkileyen hole ilk girdiğimde, üzerimde bıraktığı etki şimdi de hatırımda: Etkili büyük beyaz hol ve deniz yönündeki eyvanda her an kanatlanıp camdan çıkacak gibi duran Semadirek (Samotrake)
Nike'si... Sanırım, bu anıtsal boşluğu ilk kez bir sinema filminde görmüştüm... Hafızam beni yanıltmıyorsa, Gülşen Bubikoğlu bu görkemli merdivenlerden uçarcasına iniyordu, koltuğunun altında bir levha, aşağıda onu bekleyen ise filmin jönü Tarık Akan, Nike heykelinin biraz önünde denize doğru duruyor...

Merdivenlerden ayakları yerden kesilmişçesine inen Bubikoğlu'nun seslenişi ile dönüyor... İşte o kadraj hatırımda: Güzel zengin kız, yakışıklı delikanlı ve Akademi'nin sade ve bir o kadar da görkemli holü... Bu sahne bana belleğimin bir oyunu da olabilir... Bir Yeşilçam filminde olmasa bile, kim bilir belki tanık olduğum ve ancak filmlerde yaşanabileceğine kendimi inandırdığım gerçek yaşamdan bir sahne...

Eğitim döneminin ilk günlerinde, binanın kapısından girdiğimizde bizleri capcanlı bir salon karşıladı. İstanbul Sanat Bayramı kapsamında iki yılda bir gerçekleştirilen Yeni Eğilimler Sergisi. Osman Hamdi Holü sanat eserleri ile dolmuştu. Konferans salonunda ve oditoryumda ise 
sürekli toplantılar, söyleşiler gerçekleşiyordu. Üniversitenin holleri, koridorları insanlarla dolup taşıyor, bazı akşam üzerleri kokteyl ve dinletiler gerçekleşiyordu. İki haftalık uyum süremiz, bu geniş sanat etkinlikleri ile iç içe geçti. Kimi zaman Mimarlık Fakültesi'nde Orta Hol'deki masalarda T cetvelleri ile ilk çizgilerimizi çizdik, kimi zaman hocalarımızın teşvik ve izniyle toplantılara katıldık. Ama lise eğitiminden, hele üniversite giriş sınavından, yeni çıkmış gençler için sanırım gelinebilecek en iyi ortam burasıyd.

Işığına kavuşturulan aydınlık mekânının beslediği ve taçlandırdığg en önemli mekânlar kuşkusuz Akademi'nin temsil edildiği Osman Hamdi Salonu ve onun üst kat izinde yer alan konferans salonudur. Bu yazı ilk olarak, öğrencilik dönemimden itibaren ilgi ve dikkatimi çeken konferans salonuna 1962 yılında eklenen bölme duvarı ve onun bina ile kurduğu ilişki üzerine inşa edildi. Yanında yetişme fırsatı bulduğum değerli Hocam Utarit İzgi'nin ve Esad Suher'in yüzen duvarlar ile yeniden biçimlediği salonun bina ile kurduğu zarif ilişki, binaya dokunuşu beni uzun zamandır etkilemekteydi. Hareketli duvarları açık olarak hiç bir zaman görememiş olsam da, açıldıklarında mekânın nasıl bütünleşebildiğini hayal edebiliyordum. Birçok kişinin yaşa(ya)madı ̆̆ı, bil(e)mediği, farkına var(a)madığı, zamanla izleri silinen, yerlerine sabitlenen bu duvarları anlatmak bile yeterli olacaktı. Ancak, daha önce defalarca görmüş olduğum resimlere tekrar bakıp, açıklamaları tekrar tekrar okuyunca, bilgiler ardı ardına eklendikçe, gör(e)mediğim, yaşamadığım bir dönemin izleri yavaş yavaş gözümün önünde canlanmaya başladı. Bununla birlikte, yalnızca İzgi’nin tasarımını anlatmanın konferans salonunu anlamak için yetersiz kalacağı düşüncesi



giderek güçlenmeye başladı. Salonun tek başına değerlendirilemeyeceği, bütün içinde ve özellikle giriş salonu (bugün Resim: I Findıklı f̧ifte Saray binalarından Cemile Sultan Sarayı üst kat planı. (Eldem, 1954, 207)

Osman Hamdi Salonu) ile birlikte aynı düşünce ve tasarımın parçası olduğu biraz geç olsa da dikkatimi çekti.

İzgi'nin 1962 yılı tasarımı, Akademi'nin sosyal ortamını geliştirmeye ve biçimlendirmeye yönelik bir tasarımın mekândaki iziydi. Sanayi-î Nefise döneminden başlayarak, Akademi yaşantısı ve binasının tasarımında uzun bir dönem önemli roller üstlenen; olaylara, etkinliklere mekân olan bu salonla ilgili erişebildiğim bilgileri, arada kalan boşlukları cahilce bir cesaretle doldurarak aktarmaya çalıştım. Konunun yeni belgeler ve bilgiler eklendikçe gelişeceğine inanıyorum.

\section{Bina: Fındıklı Çifte Sarayı}

MSGSÜ merkez binaları olarak kullanılan Çifte Saray, Sultan Abdülmecid'in kızları, Cemile ve Münire Sultan için 1856 yılında yapılmıştır ${ }^{3}$ (Resim 1). Günümüzde Güzel Sanatlar Fakültesi olarak kullanılan Cemile Sultan Sarayı, Çırağan Sarayı yangını sonrasında 1913 yılından Osmanlı Meclisinin son toplantısı olan 12 Ocak 1920’ye dek Meclis-i Mebus'an toplantılarına ev sahipliği yapmıştır.4 Binada mekâna ilişkin ilk değişiklikler bu dönemde yapılmış; orta ve yan sofaların şekli değiştirilmiş, salonları takviye amaçlı direkler konmuş (Resim 2) ve asma katlar

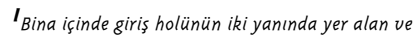
binanın zengin iç mekânlarını ışıkla dolduran aydınlık boşluklarının zeminleri küfeki taşı ile kaplıdır (Ünal ve Demir ile görüşme). 1967 yılında Ismail Hakkı Oygar'in seramik Bölümü Baskanlığı döneminde, v. Uluslararası çağdaş Seramik sergisi düzenlenmiştir. Türkiye'de bu kapsamda açılan bir ilk olma özelliği taşıyan sergi sirasında, küfeki kaplı olan aydinlık zemini, beyaz micırla kaplanmıs ve seramik eserler sergilenmiştir. sergi sona erdikten sonra micırlı yüzeyler uzun süre devam etmiştir. (Prof. Mete Ünal ile görüşme 22.11.2011; Anilanmert, 2003, 71)

2 Ne yazık ki, bu dönemde Akademi binasının

kuruluşundan beri ana girişi olan ve Nike heykeli ile özdeşlessen giriş hol (Osman Hamdi Salonu) ögrenci girişine kapatıldı. Bu tarihten sonra, o zamanki adıyla Mimar Sinan Üniversitesi'ne, ikizi olan ve ağırlıklı olarak Mimarlık Fakültesi ve bağlı bölümlerinin yer aldığı Münire Sultan bloğundan günlerine ait yeni imgeler oluştu.

3 Tarih konusunda, 0. Ceylan Istanbul Ansiklopedisi'nde yer alan "çifte saraylar" maddesinde, yapıma 1856 yılında başlanarak 1859 yılında tamamlandı̆̆ını belirtir. Pars Tuğlacı, "Osmanlı Mimarlığında Batıllıaşma Dönemi ve Balyan Ailesi" kitabında 1855 tarihini; Muhlis Türkmen ise MSÜ binalarının geçirdiği dönemsel değisiklikleri ele aldığı yazısı "Tasarım ve Kenarda Kalan Düşünceler" de 1860 tarihini vermektedir.

4/6 Mart 1920'de istanbul'un işgali sirasında ingiliz gemilerinin topları bina üzerine çeurilmiş, bazı mebusların Malta'ya sürülmesi olayı da yine bu binada gerçekleşmiştir.

$\boldsymbol{S}_{1926}$ tarihine iki kaynakta rastlanmaktadir: I-Anonim. 1940 "Güzel Sanatlar Akademisi" tanıtım kitapsı̆̋̆ı. (Kitap̧̧ı üzerinde basım tarihi yoktur, ancak 1940 yılında açılmıs ve açılacak olan sergilerden bahsetmesi, 1940 yılı ortalarında basılmış olduğunu göstermektedir.)

2- CEZAR, Mustafa. 1973. "Kuruluşundan bugün 2- CEZAR, Mustafa. 1973. "Kurulusundan bugune
Akademi" Devlet Güzel Sanatlar Akademisi [1883-1973] 90. yıl kitapsı̆̆ı. DGSA yayını. istanbul.

$\boldsymbol{\sigma}_{1928}$ yılında Güzel Sanatlar Akademisi adını alacaktır (Küçükerman, 2005, 19).

$7_{\text {Eldem ve Handan tarafindan Akademi binasının inşas }}$ sonrasinda yayımlanan yazıda kullanılan plan, Eldem'in Türk Evi Plan Tipleri (ITÜ, 1954) kitabinda da aynı çizim detay ve tekniğinde yer almaktadır. Bu planlarda, binaya sonradan eklenen ve fotoğraflarda görülen kolon dizileri gösterilmemiștir. girilmeye başlandı. Genç kuşakların belleklerinde ilk 


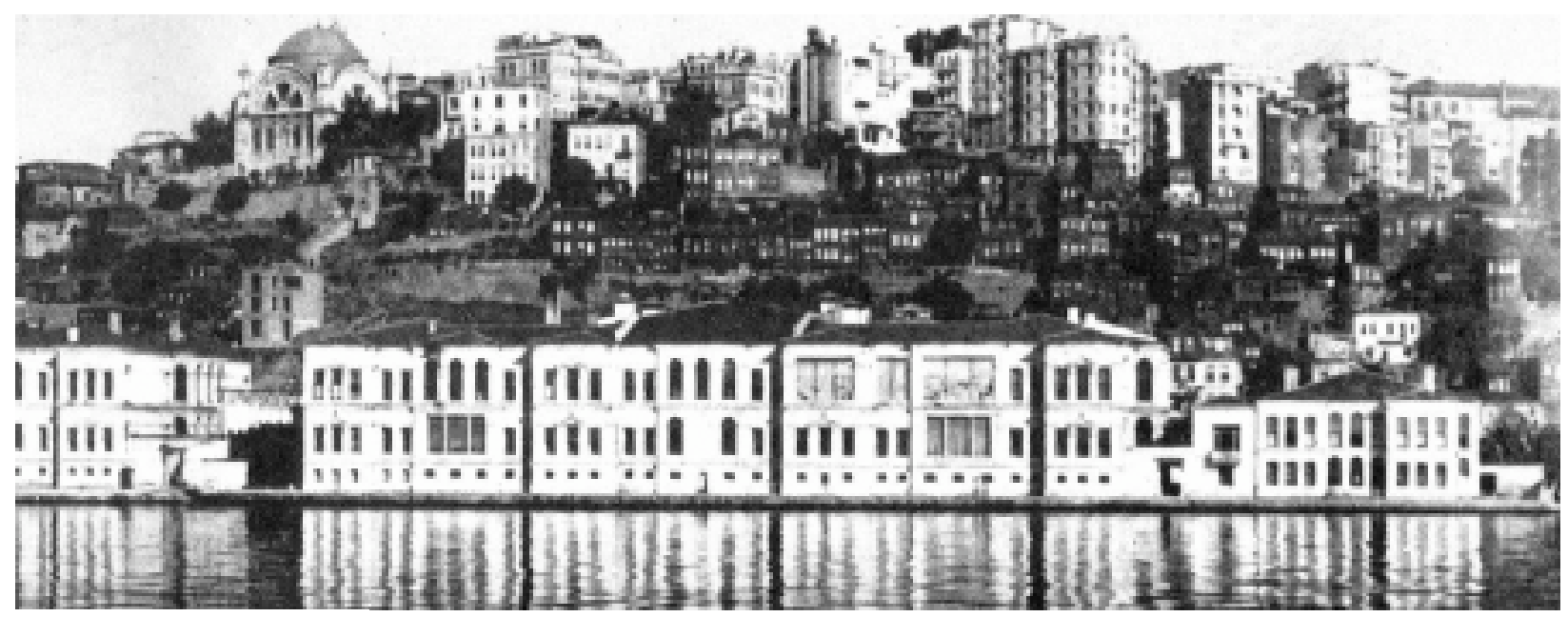

Resim: 3

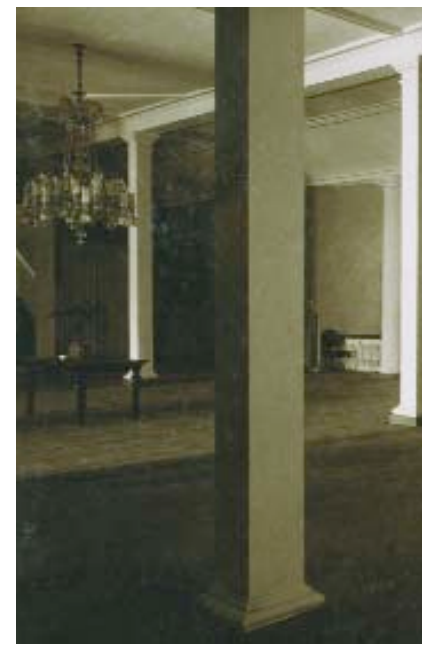

Resim: 2

Resim: 2 Giriş Sofası

Akademi binasinin 1948 yanginı öncesi fotoğrafları arasında yer alan bu fotoğrafta, salona muhtemelen üst sofaya kurulan Meclis Salonunu desteklemek amaçlı olarak eklenen kolon dizisi görülmektedir. (MSGSÜ Rektörlüğü Fotoğraf Atölyesi Arşivi, 1953)

Resim: 3 Findıklı fifte Saray binalarından Cemile Sultan Sarayı bloğu, Resim Atölyelerinin yer aldığı kanadın cephesinde birleştirilmiş pencereler dikkat fekmektedir. (Eldem, 1995, 21) inşa edilmiştir (Eldem ve Handan, 1954, 7).

Binanın Akademi'den önceki son konuğu ise İstiklal Mahkemesidir. Akademi, Meclisten sonra İstiklal Mahkemesi tarafından da kullanılan merkezi sofasalonu bir süre konferans salonu olarak kullanmıştır (Silivrili, 2003, 72).

1926 yılındas, Atatürk'ün iradesi ve T.C. Meclisi'nin onayı ile o zaman ki adıyla Sanayi-î Nefise Mekteb- î Âlisi'ne 6 devredilen saray binası, mekânlarında hanedan döneminin görkemli izlerinin yanı sıra bir dönemin tarihsel izlerini de koruyarak eğitim binasına dönüştürülmüştür. Bu süreçte; Akademi'nin eğitim ihtiyaçlarının karşılanması sırasında kuzey yönündeki yan sofa, ikiye bölünerek resim atölyelerine tahsis edilmiş, Münire Sultan Sarayı yönündeki yan sofa bölünerek kütüphaneye ayrılmış, üst katta daha önce meclis salonu olarak kullanılan merkezi orta sofa ise konferans salonu olarak kullanılmıştır (Eldem ve Handan, 1954, 8). Bu dönemde, resim ve heykel atölyelerine daha fazla 1şık alabilmek için, cephede yer alan ikili ve üçlü pencere grupları birleştirilerek büyük 1şık yüzeyleri açılmıştır (Resim 3).

Akademi binasının zeminden yüksek giriş holü, bu binada okuma firsatı yakalamış tüm hocaların ifade ettiği gibi etkileyici özelliklerini korumaktadır. 1940’lı yıllardan 1960'lı yıllara kadar süre gelen cumartesi tanışma çaylarının yapıldı̆̆ tango ve fokstrot müzikleri eşliğinde dans toplantılarının düzenlendiği, öğrencilerin misafirlerini ağırladıkları salon (Tarcan, 2003, 38), bu dönemde eski saray sofası niteliğini sürdürmüştür. Binanın yangın öncesi fotoğraflarında, koridor izinde görülen sıra kolonlar, üst kat sofasının meclis salonu olarak kullanıldığ 1 dönemde döşemeyi desteklemek amacıyla eklenmiştir. Yapının bilinen rölövesinde bu kolon sırası görülmemektedir. ${ }^{7}$ 
1926 yılı Sanayi-î Nefise Mekteb-î Âlisi için yerleşik düzenin başlangıcıdır. Ana binaya Resim, Tezyînî Sanatlar ve Mimarlık bölümleri ile yönetim birimleri ve kütüphane yerleşir. Heykel Bölümü ise bahçedeki binaları kullanır. Ancak bu rahatlama çok kısa sürecektir. 1948 yılı Nisan ayının ilk günü, bir elektrik kontağından kaynaklanan yangın, hanedandan miras Akademi mekânına uzun süre onarılamayacak kadar büyük hasar verecektir. Yangın yalnızca mekâna değil, aynı zamanda önemli bir birikime sahip kütüphane, öğrenci kayıtları, saray döneminden kalma eşya ve tablolar, öğrenci belgelemelerinden oluşan Milli Mimari Semineri Arşivi ${ }^{8}$ de dâhil yerine konulamayacak birçok kayba da sebep olmuştur ${ }^{9}$.

Yangın, Akademi için ikinci bir göçebelik döneminin başlangıcıdır. Bu süreçte, mimarlık bölümü dışındaki bölümler bahçede yer alan ve yangından zarar görmeyen binalara, yönetim Taut Atölyesi olarak bilinen, Harem bahçesi içindeki salona yerleşmiştir (Cezar, 1973). Mimarlık Bölümü ise 1948 yılını, Fındıklı

Yokuşunda Fransız mimar Georges Debés tarafından yapılan ilkokul binasında (İnönü Illkokulu), sonraki dönemleri ise Yıldız'da

Sağır ve Dilsizler Okulu'nun ${ }^{\prime \circ}$ bulunduğu binada sürdürmüştür (Cezar, 1973).

Yangın sonrasında bir süre sessiz kalan Akademi, dönemin Cumhurbaşkanı İsmet İnönü'nün ilgisi ile yenileme için kaynak bulacaktır. Yenileme projesi için Akademi Müdürü Zeki Faik İzer'in"' de içinde bulunduğu, Yüksek Mimarlık Bölümü proje hocaları, Sedad Hakkı Eldem, Arif Hitmey Holtay, Ahsen Yapanar, Mehmet Ali Handan, Asım Mutlu, Halit Femir, Feridun Akozan'dan oluşan bir komisyon kurulmuştur'2 ${ }^{\prime 2}$ Bu komisyon, ilk olarak ihtiyaç programını hazırlamış ve buna göre çalışmalarına başlamıştır. Komisyon üyelerinden Yüksek Mimarlık Bölümü şefi ve atölye öğretmeni Arif Hikmet Holtay bir proje, Atölye ve Milli Mimari Semineri öğretmeni Sedad Hakkı Eldem ile Atölye öğretmeni Mehmet Ali Handan'3 birlikte ayrı bir proje hazırlayarak komisyon değerlendirmesine sunmuştur (Eldem ve Handan, 1954, 9).

Akademi yönetimi tarafından Arif Hikmet Holtay Hocanın projesinin uygulanması önerilse de, Eldem ve Handan hocaların hazırladıkları proje oy çokluğu ile kabul edilmiş ve uygulanmıştır (Eldem ve Handan, 1954; Türkmen, 1999, 6) 14.

Türkmen, asistanlığı sırasında uygulama projelerinin çizimi ile görevlendirildiği yenileme projesinin yaklaşımları ile ilgili düşüncelerini;

“...bu mimari düşünce ve uygulama saray

kalıntısından tamamen styrılıp, genç, dinamik ve onurlu bir mimariye gidişin bir anlatımı olarak da kabul edilebilir."

$(1999,2)$

sözleriyle ifade eder. Türkmen'e göre yeni binanın iki eksiği vardır; duvarlarında asılı olan Goya, Velasquez, Ingress gibi ressamların kopyaları ile hoca ve öğrencilerin okul içinde giydikleri beyaz önlükler...

Bülent Özer, Eldem ve Handan'ın Akademi binasının yenileme projesiyle ilgili olarak;

“...yerine çağdaş olmakla beraber eskisiyle özsel bir bă̆lant»* içinde bulunan ve rahmetli Prof. Mehmet Ali

Handan'ın etkili katkısıyla, yine rahmetli Prof. Sedad Hakkı Eldem tarafından bugünkü başarılı bina inşa edilmiş.” (2003, 218-219) yorumunu getirir.

Günümüzde ana ilkeleri okunabilen bu projenin özelliğgi, yı ğma kâgir dış duvarların korunarak, içinin yalın, brütalist bir anlayışla betonarme olarak yeniden inşa edilmesidir. Proje, sahil sarayın sofalarını

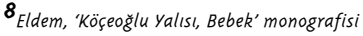
girişinde, Kösceoğlu Yalısı'na ait çalışmaların, rölövelerin tümü ile birlikte kül olduğunu belirtir $(1977,9)$. Ancak, yangindan Eldem'in, kitap çalısmaları (Türk Evi) için kullandığı bir kısım doküman kurtulmus olmalıdır.

9 yangin sirasında Selamlık Köşkü hasar görmemiş ve eğitim amaçlı olarak kullanılmaya devam edilmiştir. Ancak daha sonra lodos dönemlerinde zemininde yaşanan problemler nedeniyle yıktırılmıştır. Sahil yolunun açılması sırasında Kösk, 2000 yılında Mimarlık Bölümü emekli ögretim üyesi Prof. $R$. Rusen Dora tarafindan yapilan arșiv çalışmaları neticesinde, kendisi tarafından hazirlanan restitüsyon ve restorasyon projeleri ile üniversitenin idari binası olarak yeniden yapilmıștir (Dora, 2000, 24-25).

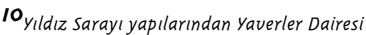
olarak bilinen yapı, günümüzde Yıldiz Tekni Üniversitesi Iktisadi ve idari Bilimler Fakültesi binasi olarak kullanilmaktadir.

"I Zeki Faik Izer, 5 Kasım 1948 ile 25 Kasım 1952 tarihleri arasında müdürlük yapmıştır. Bu dönem Akademi'nin mekân açısından en sıkıntılı ve zorda kaldı̆̌ı dönemdir. Cemile sultan Sarayı, Izer'in basskanlı̌̆ı döneminde yenilenmiştir.

12 Türkmen bu görevin Akademi Yönetimi tarafından Yüksek Mimarlık Bölümü Atölye Hocaları Kurulu'na verildiği bilgisini aktarır. $(1999,2)$

13....... Ali Handan, Sedad Hakkı Eldem'in yanindan Ahmet Ağaoğlu Evinin (1936-37) proje ve uygulamasina henüz ikinci sinf örrencisi iken hatılmis, yaloua Termal Oteli (1934-37) ve inhisarlar Genel Müdürlüğ̈̈ (193437)'nün mobilya ve detayları ile kısmen kontrollüğünü yapmıs ve hocası Eldem ile okul süresince ve onu takip eden yillarda bir çok önemli yarısmalara katılmıstır." (Gubuk, 1984) Ayrıca Eldem ile birlikte yaptı̌̆ı çalışmalarla ilgili bilgiler Mehmet Ali Hoca'nin kendi sözleri ile Arredomento Dekorasyon, "Türk Mimarisinin Mihenk Taşı: Sedad Hakkı Eldem" özel sayısı içinde (Eylül 1990, 84)'de yer almaktadır.

14 Akademi binasının uygulama yükleniciliğini, Inönü Stadyumu (projesi șinasi şahingiray ve italyan mimar Vietti Violi ile), spor ve Sergi sarayı (bugün Lütfi Kırdar Kongre Salonu)'nın da proje ve uygulamalarını yapan Akademi eski mezunlarindan Y. Mimar Fazıl Aysu (1936 mezunu) gerçekleştirmiştir.

* Alintilar içindeki vurgular yazar tarafindan verilmiştir. 
Resim 4 a-b:

Aydınlık Boşluğu-

Akademi binasinın masif kitlesinin içinde açılan iki büyük aydınlık, binanın içinde koridor ve salonları gün ışı̆̆ ile doldurur. Aynı zamanda tasarımda istenilen bütüncül mekânın oluşturulmasında da bu aydınlıkların büyük katkısı vardır. Aydınlıkların zemini yağmur sularını ortada toplayarak, tahliye edecek biçimde, dört köşeden merkeze doğru ĕgimlidir. Çatıdan toplanan yă̆mur suları da aydınlığın is kösselerinden indirilerek aynı tahliye fılkışına bağlanmıştır.

Aydınlığın feuresi cam yüzeylerle dış etkiye kapatılırken, fapraz merdi-

venlerin bulunduğu yüzey I.ve 2. Kat seviyelerinde düşey etkili cam tuğla ile kurulmuştur.

Ne yazık ki artan mekân ihtiyaçlarına fözüm bulma gayesiyle eski rektörlük tarafındaki aydınlık 1990'lı yılların başında, diğer aydınlık ise önce seramik atölyesi olarak kullanılmak üzere 1972'de giriş katı seviyesinde, 1997'de de üst katları kapatılmak suretiyle mekâna katılmıştır. (Gülmez, 20II, 19) Bugün Bomonti binasinın tamamlanması ve bazı birimlerin taşınması imkanı ve çelik yapının özgün yapıya getirdiği fiziksel yük ve statik sorunlar nedeniyle, aydınlık boşluğu yeniden açılmıştır.

(Eldem ve Handan, 1954, 14)

$15_{\text {Ancak, belki mimarlarin tasarımina }}$ karşı gösterilen aşırı bir hassasiyet belki de bir ihmal sonucu 2000'li yillarin başında sözkonusu aydınlık boşluğu kapatılırken eksen üzerinde buluna kolon, zemin kat ve birinci katta kaldırılmış, konferans salonu katında ise dokunulmamıştır. Bu kolonun varlı̆ı inşa sirasinda çekilen fotoğraflarda ve salonda farklı zamanlarda yapılan etkinliklerin belgelendiği fotoğraflarda $1990^{\prime} l ı$ yilların sonuna dek açıkça görülmektedir.

$16_{\text {Atatürk Kız Lisesi olarak kullanılmakta }}$ olan Münire Sultan Sarayı, 1969 yilında 0 zamanki adiyla IDGSA'y a deuredilmistir. Prof. Sedad Hakkı Eldem tarafindan 1974 yılında iç kısmı tamamen yıkılarak, ilk binada uygulanan tasarım ilkeleri doğrultusunda yenilenen yapi, 23 Nisan 1975 yılında eğitime açılmış ve Mimarlık Bölümü’nün kullanımına verilmiștir. (Eldem, 1983, 212-222)

$17_{i k i}$ yapının yenileme projeleri özünde aynı gibi görünse de taşıııı sistemde ve özellikle ince yapı detaylarinda önemli farkliliklar bulunmaktadir. Ilk uygulama olan Cemile sultan bloğunda detaylar tasarım anlayışının sürdürüldüğü, bütün leştirici ayrıntılar olarak dikkat çeker.
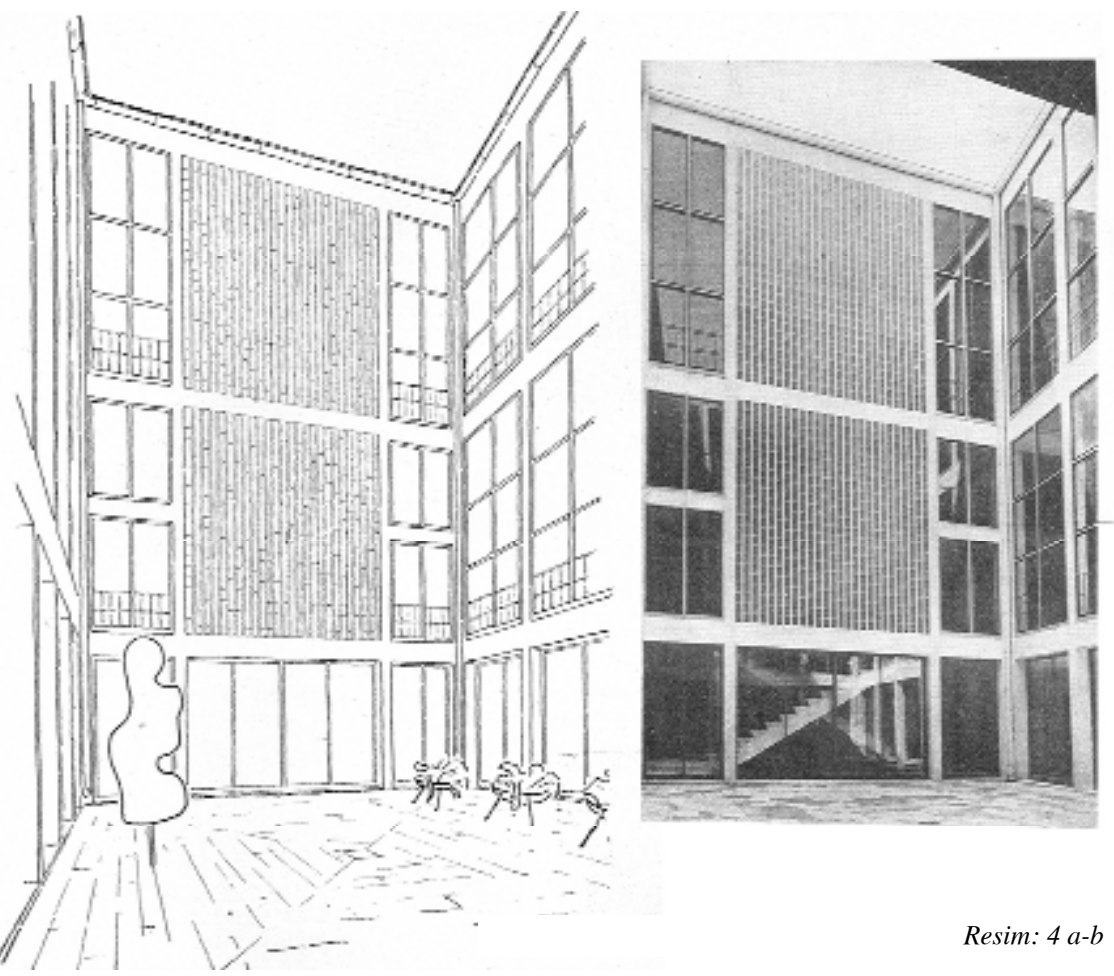

yorumlayarak değerlendirmiş ve saray dönemine ait dar 1şıklıklarını geniş aydınlıklara dönüştürerek 1şıklı ve saydam, geçirgen bir iç mekân yaratmayı hedeflenmiştir (Resim $4 a$-b). Yenileme projesinin kuşkusuz en etkili yönü, Eldem ve Handan'ın saray sofasına getirdikleri yorumdur. Sofa, giriş katında bir karşılama-temsil mekânı olarak kara ile denizin arasında, yüksek tavanlı olarak yeniden biçim kazanır. Beşiktaş ve Tophane yüksek tavanlı giriş holünü destekleyen aydınlıklar, mekânın merkezî etkisini güçlendirdiği gibi, bina içinde mekânlar arası görsel ilişkiyi bütünler. Holü sınırlandıran kolon dizisi, denize paralel eksen üzerinde eksiltilerek, aydınlık boşlukları ile merkezî hol ilişkisi güçlendirilmiştir. Böylelikle plânda haçvarî biçime sahip giriş holüne, kara ve deniz yönündeki eksene dik olarak bina içine uzanan ikinci bir eksen ile merkezî hol karakteri kazandırılmıştır (Resim 5). Ancak uygulama sirasında bu eksen üzerinde Tophane yönünde bulunan aydınlık boşluğunun aksına bir kolon yerleştirilmiş, böylelikle mimarların aradığı merkezî etki tam karşılığını bulamamıştır.I5 Mimarlar, üst katta çok amaçlı olarak planlanan salonu sınırlandıran çizgide, alt kattaki kolonlardan farklı eksende, mekânı biçimsel olarak sınırlandıran yalancı kolonlar kullanarak üst holün, merkezi hol/sofa karakterini sürdürmüşlerdir.

1952 yılı yenileme projesindeki bu duyarlılık, 1974-76 yılları arasında yenilenen ve ana tasarım ilkesi Cemile Sultan Sarayı bloğu ile aynı olan Münîre Sultan Sarayı bloğu yenilemesinde görülmez ${ }^{16}$. Bu blokta taşıyıcı sistem, yapının uzun ekseni üzerinde merkezi holü/salonu vurgulamaz ${ }^{17}$.

Masif kabuk içinde geçirgen iç mekânların oluşturulmasına olanak sağlayan, taşıyıcı sistem çözümündeki narinliktir. 1976 yılında yenilenen olan Münire Sultan 


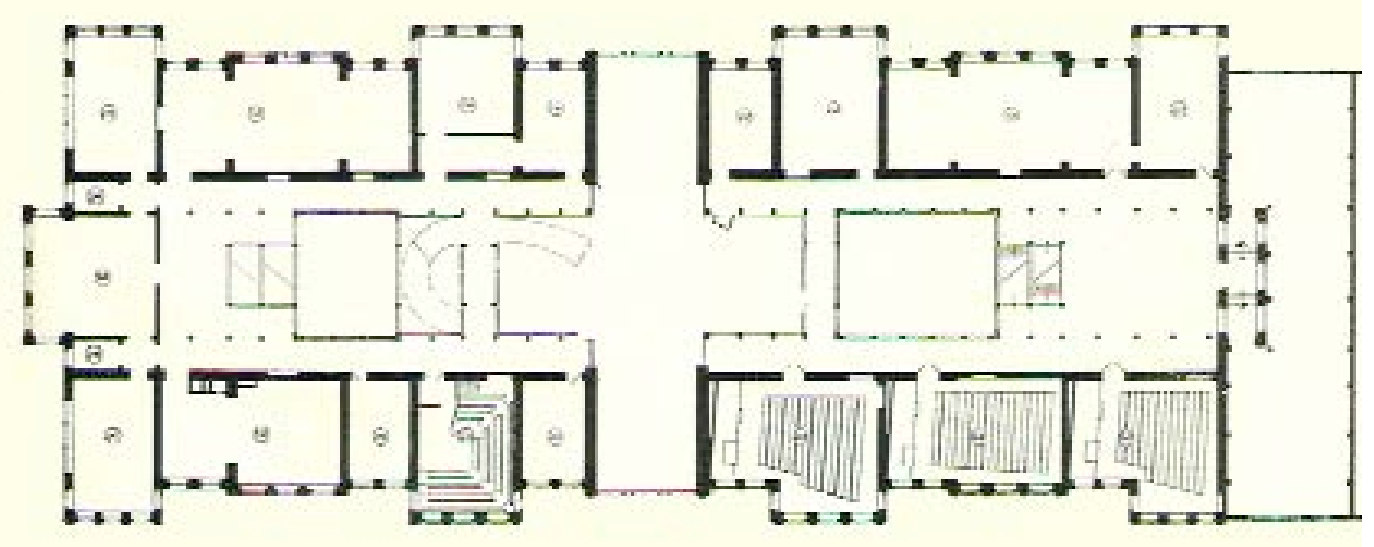

bloğunun iç mekânında aynı yaklaşım görülmez. Tasarım ilkeleri aynı gibi görülse de iki binayı bütünüyle farklılaştıran temel ilke iç mekânda aranan narinlik ve şeffaflıktır. Binanın iç mekânlarının kaldırılarak bütünüyle açık bir plânlama anlayışının benimsenmesi, tüm dönemlerinde mekân yetersizliği sorunu olan bir kurum için cesur bir karardır. Muhlis Türkmen Hoca, yanan binanın rölövesi üzerine Sedad Eldem Hoca tarafından dolmakalem ile yapılan çizimin, berrak, temiz, neler yapmak istediğini bilen çizgilerle, ölçülü ve inşaî bir karakterde olduğunu aktarır (1999, 2).

Binanın iç kısımda inşa edilen yeni betonarme yapı olabildiğince narin ve hafif çözümlenmiştir. Bu tasarım anlayışı, uygulama detaylarında da yalın bir sadelik içinde sürdürülmüştür. Sade, yalın malzeme-detay kullanımı, tasarımın ana prensibini oluşturur. Brütalist bir anlayışla malzemeler, kendi kimliklerini uygulama izleri ve kusurlarını gizlemeksizin yansıtırlar. Yapı, geçmiş zengin yaşamının izlerini gizlemek istercesine yalınlaştırılmıştır. Büyük hol döşemeleri beyaz mermer kaplanmış, böylelikle büyük boşluk ve aydınlıklardan içeri giren ışı ̆̆ın mekânı olabildiğince doldurması sağlanmıştır. Aydınlık, yalın ve olabildiğince serbest iç mekân, Akademi'nin yangın öncesi saray döneminden miras, renkli ve loş mekânları ile bir tezat içindedir. Bu kararda yapının yeni işlevinin rolü tartışılmaz olmalıdır. Bu noktada tartışılabilecek olan bir kavram, binanın iç mekânlarında ve cephesinde yapıldığ 1 döneme ve mimarisine uygun bir yenilemenin yapılmamış olmasıdır. Bunun nedeninin, Eldem'in eski yapılara duyduğu hayranlığın arkasında bir araştırmacı olarak öğrenme isteğinin, yeni bir mimarinin ipuçlarını arama ve çözümleme isteğinin olduğu söylenebilir. Köçeoğlu Yalısı monografisi önsözünde Eldem, yapının belgelenmesinin yanı sıra yaklaşık bir yıl süren yıkım süresinde yaptığı sık ziyaretlerle "tersine inşa edilircesine" izlediğ $i$ ayrıntıları ve yapı şekillerini tespit edebildiğini aktarır. Yıkım süreci onun için bir başka öğrenim süreci olmuştur. Onun için geleneksel mimari çağdaş mimari için bir kaynak araştırma alanıdır. Bu nedenle eskiye bakışı bugünkü anlamıyla restorasyon kavramının kapsamı dışındadır. Akademi binasının 1952 yenilemesi de o yüzden özgün ve başarılı bir örnek olarak değerlendirilmelidir.
Resim: 5

Tasarı Plan: Eldem ve Handan tarafindan hazırlanan projenin birinci kat planı. Daha sonra eklenen birinci kat geçidi projede yer almamaktadir. Taut Atölyesi olarak bilinen Harem bahçesindeki yapı ve önündeki sofa yeni projede de sürdürülmüştür. (Eldem ve Handan, 1954, 15) 


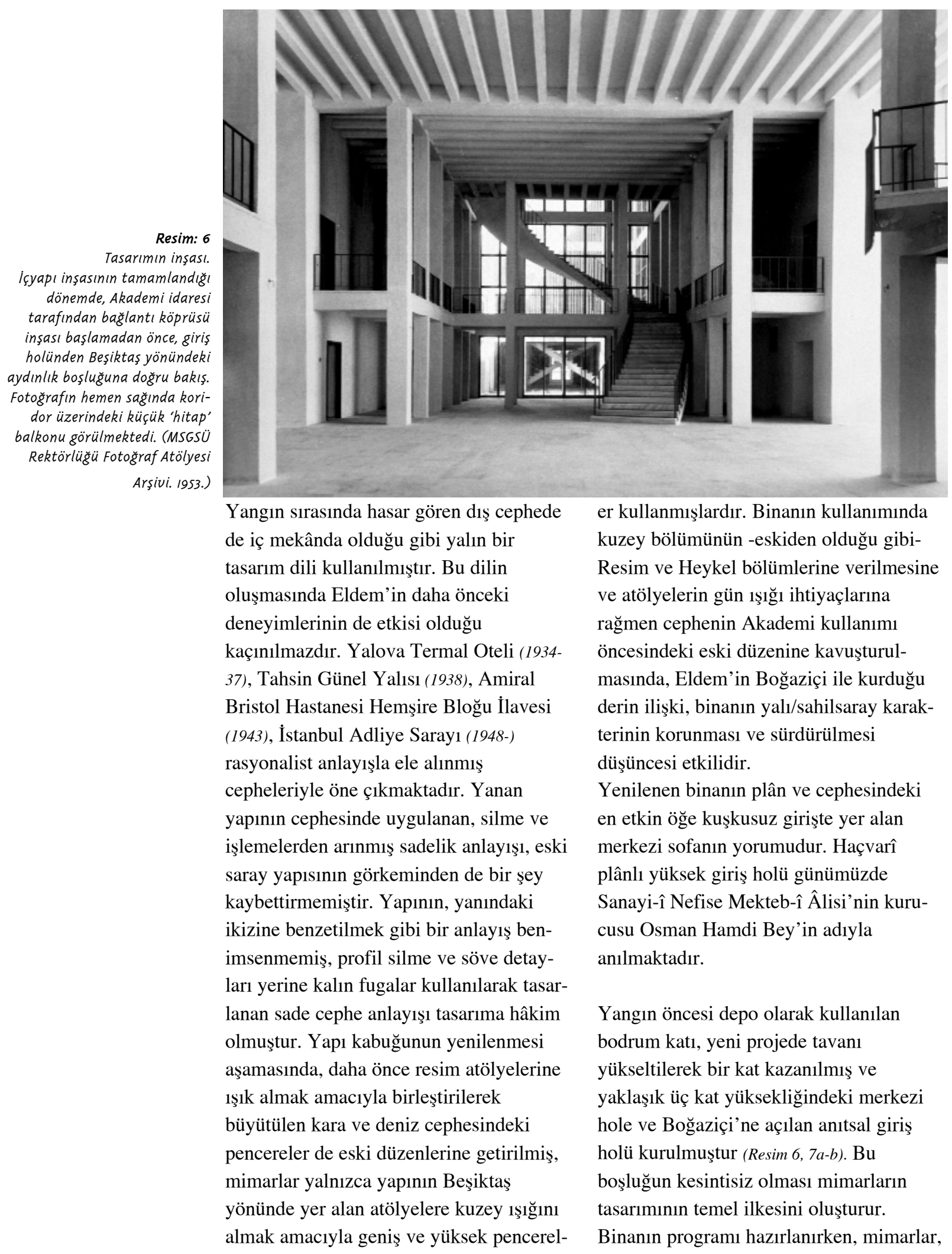




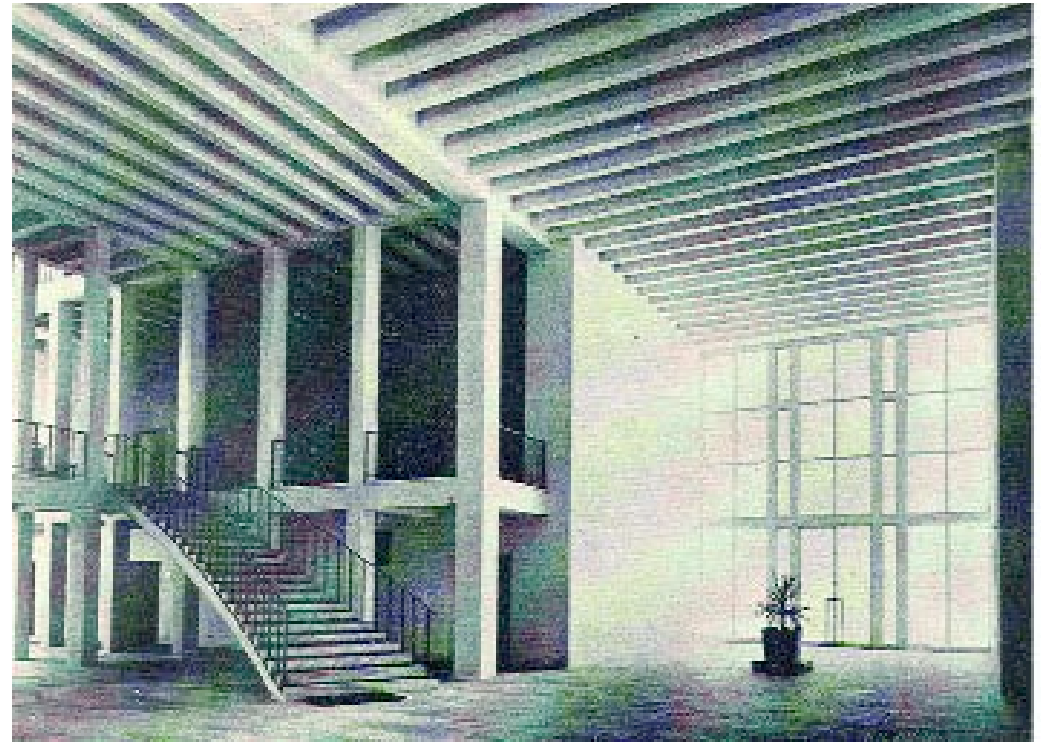

orta boşluğu yaratabilmek amaciyla programı da yorumlamış ve binayı yatayda iki kanada ayırmıştır. Ana girişe göre orta boşluğun sağında kalan kanadı Mimarlık Bölümü'ne, solunda kalan kanadı ise Resim Bölümü ve kütüphane için ayrılmıştır. Programın düşeyde ki yorumunda ise zemin katlar öğrencilerle ilgili mekânlar, dışa açık mekânlar ve idari birimlere ayrılmış, üst kat ise, Akademi'nin ilerideki karşılaşacağı ihtiyaçlar göz önünde tutularak; hoca ve asistan odalarına ve resim atölyelerine ayrılmıştır. Üst katta, orta holün üzerinde yer alan büyük salon ise, Akademi'nin konferans ve sergi ihtiyacını karşılamak üzere plânlanmıştır (Eldem ve Handan, 1953, 12). Bu esnek kullanım, Eldem ve Handan'ın öğrenci oldukları dönemde üst sofanın kullanımı ile aynıdır. Eski sofa, yenileme projesinde üst hol olarak adlandırılmıştır.

Merkezi giriş holü (Osman Hamdi Holü), binayı iki parçaya ayırmaktadır (Resim 5). Resim, Heykel ve Tezyini Sanatlar bölümleri ile diğer kanatta Mimarlık Bölümü'nden oluşan, bu iki kısım, giriş katı ve üst katta sofalar üzerinden bağlanmaktadır. Binanın işleyişinde son derece önemli görevleri olan ve plân kurgusunda salon, dolaşım alanları ve iç boşlukların oluşturduğu yeni tasarım ile binanın iç beden duvarları arasında yer alan koridorların; mimarlar tarafından birinci katta çıkmaz sokaklara dönüştürülmesi, zor ve bir o kadar da cesur bir karardır. İki genç mimarın 'ehemmi mühimme'/8 tercih ederek, bina içinde aranan büyük iç boşluğu kurabilmek amaciyla binanın işleyişini zorlaştıracak biçimde programı yorumlayarak mekân düzenlerini çözümlemeleri, Akademi'ye kısa süreli de olsa modern ve anıtsal ölçülerde, çevre ile bütünleşen ve çevresindeki mekânları bütünleştiren bir büyük hol kazanma fırsatı sunmuştur. Bu çözüm yapının saray dönemi sofasına ait referanslar içermektedir. Ancak tasarımda, bina içinde sofanın olmadığı bir ara kat yapılmış ve kanatlar arası bağlantı bu katta kesilmiştir (Resim $8 a$ b).

Bina kullanılmaya başladığında, Akademi yönetiminin, mimarların hazırladığı projenin yerleşim ilkelerinin dışında bir kararla idari büroları, birinci kata yerleştirmesi ile binanın işleyişinde sıkıntılar oluşmuş ve kanatlar arasında

\footnotetext{
$\mathbf{1}_{\text {Ehemmi mühimme tercih etmek', önemli olanı }}$ daha önemli olanin gerisinde tutmak... Mehmet Ali Handan Hoca'nin mimarlık ögretisinin temellerinden biridir ve bizlerin de o'nun ögrencisi olan hocalarımızdan duyduğumuz, öğrendiğimiz ve uygulamaya çalıștı̆ı̆ıı bir düsturdur. Mimarlık uygulama pratiği de 'ehemmi mühimme tercih etme' üzerine kuruludur.
} 

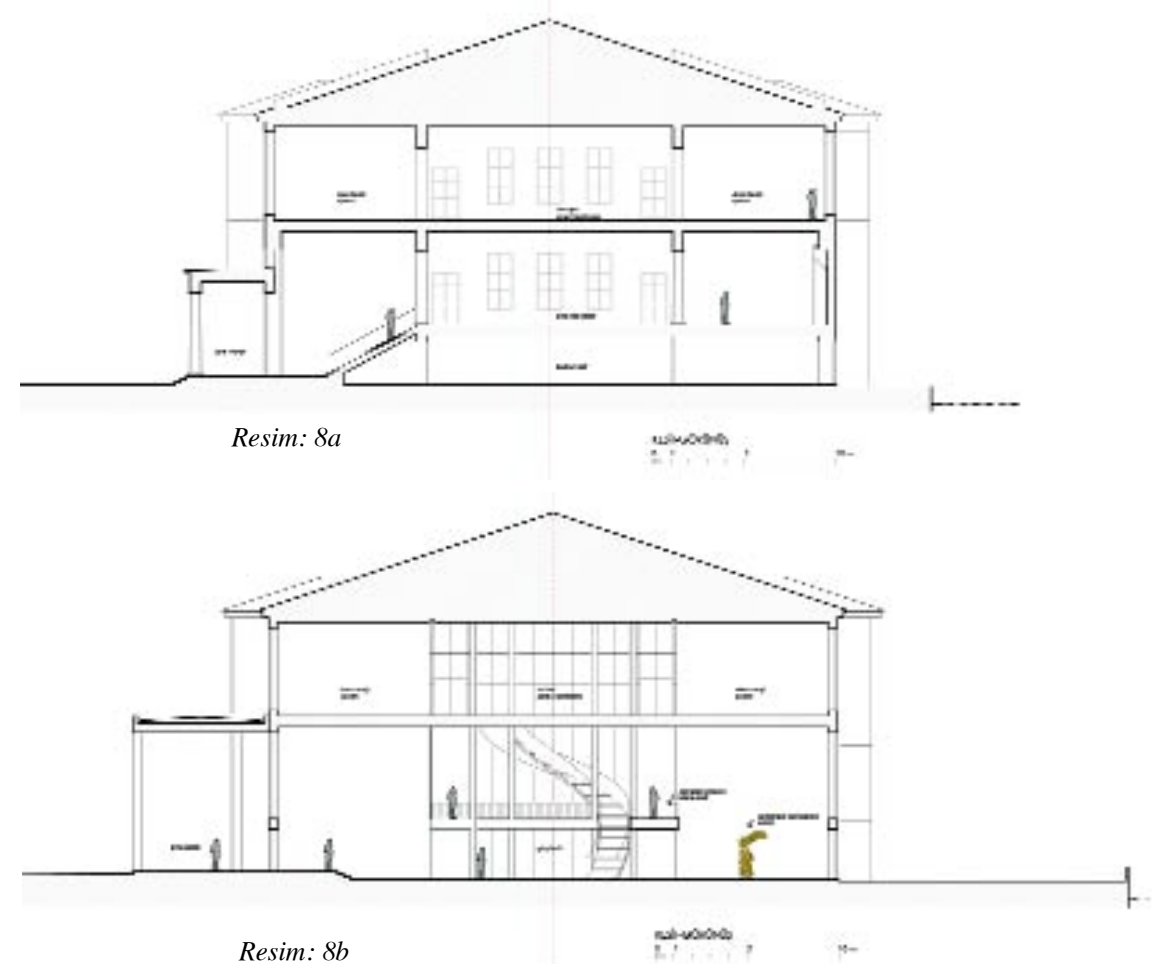

Resim: $8 a$ 1948 yangını öncesine ait restitüsyon kesiti. (Aysel, 20II)

Resim: 86 1952 yenilemesi sonrasina ait restitüsyon kesiti. (Aysel, 20II) iki kesit arasındaki önemli farklılık; giriş katı sofasının, bodrum kat ile birleştirilmesi ve is mekândaki şeffaflık arayışıdır. Giriş saçağı binaya 1960'lı yıllarda eklenmiştir.

19 Köprü, Zeki Faik Izer'in Akademi Müdürlüğü döneminde Mimarlik Bölümü şehircilik ve Topoğrafya dersi hocası Şakir Tunç tarafindan projelendirilerek yapılmıştır. (Esad suher ile görüssme, 28.10.2011)

20 Türk Evi Plan Tipleri kitabının ilk baskısı 1955 yılında iTÜ tarafindan yapılmıștir, Akademi'nin yangin sonrasi yenilemesi ise 1952-1954 yillari arasindadir. bağlantı sorunu gündeme gelmiştir. Eldem ve Handan'ın muhalif görüşlerine karşın, Akademi Yönetimi, bina içindeki işleyiş sıkıntısını gerekçe göstererek, orta boşluğun ayırdığı iki kanadı birleştirmek amaciyla, deniz yönünde birinci katta yer alan koridorun sürekliliğini bir köprü ile sağlamak kararı almıştır. Bina inşasının tamamlanmasının ardından yapılan bu ilk müdahale ile bugünkü bağlantı köprüsü yapılmıştır'9 (Resim 6-7).

Mimarlar, kanatlar arasında birinci kat koridorunda bir bağlantıyı önceden düşündüklerini, uygulananın aksine, kara tarafında yer alan koridorları birbirine bağlayan zarif bir köprü projesini de önceden hazırlayarak, ileride yapılması ihtimaline karşı inşa sırasında yerinde gerekli önlemleri aldıklarını belirtirler (Eldem ve Handan, 1954, 13). Böylece, köprünün giriş yönündeki koridoru bağlaması ile giriş holü mekânsal olarak sınırlanacak, orta boşluğun deniz ile olan görsel ilişkisi de kesintiye uğramayacaktır.

\section{Büyük Salon / Merkezi Sofa}

Sarayın merkezi sofası olan orta boşluğun, üst katta çok amaçlı büyük bir salon olarak değerlendirilmesi bütün içinde ayrı bir önem taşımaktadır. Yapının saray olarak kullanıldığı dönemde de plân içindeki en güçlü öğe, merkezi sofadır. Merkezi plân kavramını güçlendiren sofa, özellikle Boğaziçi kıyılarında kara ve deniz yönündeki eyvanları ile ayırt edici bir plân tipi gelişiminin son aşamasıdır. Orta sofanın en belirgin olduğu plân tiplerinde sofa, oda boyutlarındaki eyvanların aracılığıyla iki yönde dişa açılmaktadır (Aysel, 2004, 234). Merkezi sofanın biçimsel olarak öne çıkarıldı ğ1, üst örtüsünün özelleştirildiği örneklerde (daire/oval sofa) eyvanlar, tavan ve döşemedeki kot farklılıkları ile ve bazen de mekânı görsel olarak bölen kolon dizisi ile sofadan mekânsal olarak ayrılırlar. Bu mekânsal ayrılma, bir kullanım farkının da sonucudur. Oturma mekânı olarak çok büyük ölçülerde olan merkezi sofanın belirli özel toplantılar dişında pek sık kullanılamayacağı da kesindir.

Hanedanın temsil mekânları içinde yer alan Sultan Saraylarının, orta sofaları, batılı anlamda bir salon karakterindedir. Orta sofaya yüklenen temsil işlevi, günlük yaşam işlevlerinin belirlediği boyut ve biçimlenişin dişında, sofaya plân içinde ayırt edici bir özellik kazandırır (Akın, 1990, 179).

Eldem, yanan Akademi için yenileme projesini hazırladığı dönemde (1952-54), Milli Mimari Arşivi verilerinin bir sonuç değerlendirmesi niteliğindeki 'Türk Evi Plân Tipleri’ kitabını yayına hazırlamış ya da hazırlıyor olmalıdır. ${ }^{20}$ Bu çalışmada, Eldem'in Türk Evi tipolojisini 'sofa'nın plân düzeni içindeki yeri ve gelişimi üzerine kurmuş olması da kanaatimizce değerlendirilmesi gereken bir konudur. 

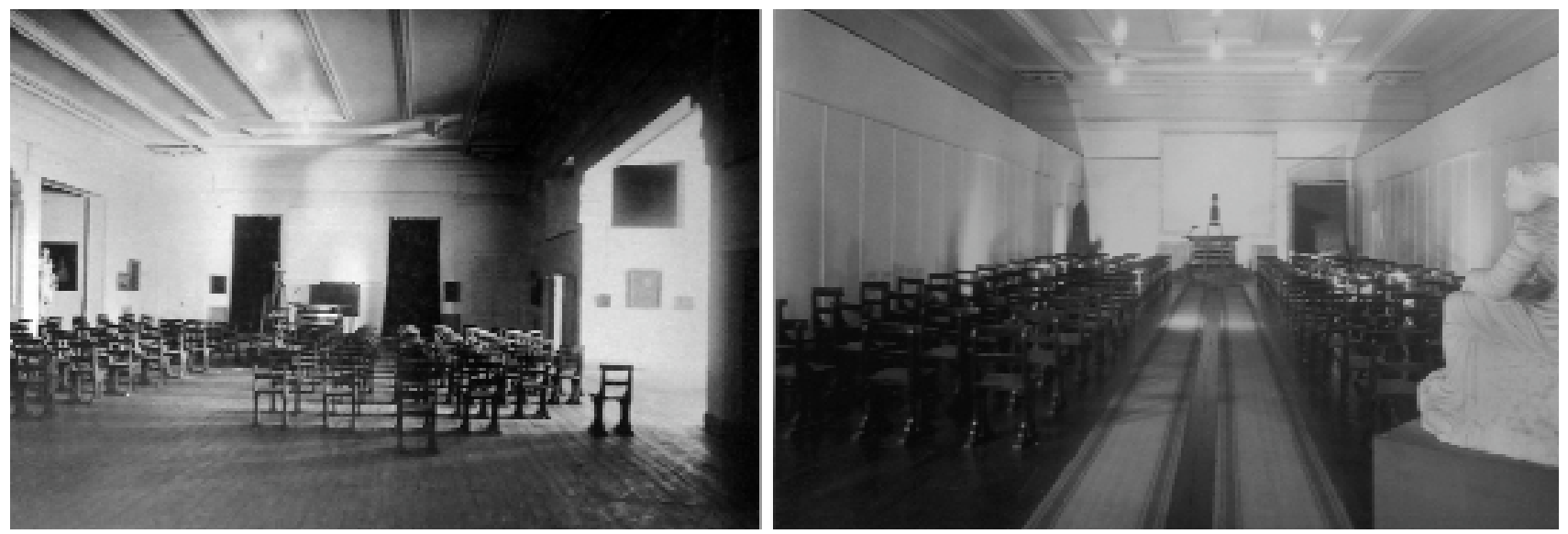

Resim: $9 a-b$

Yenileme projesinde orta sofa, yeni Akademi binası için bir merkez niteliğindedir. Giriş katında eskiye oranla yüksekliği artırılan sofa, itibarlı bir giriş ve aydınlık bir sergi holü olarak değerlendirilir. Üst katta plânlanan sofa ise Akademi'nin binayı kullandığg dönemlerde olduğu gibi toplantılara olanak sağlayacak şekilde düzenlenmiştir. Yeni çözümlemenin, yangın öncesi kullanım ile bir başka mekânsal farklılığg ise, giriş katında kara ve deniz yönündeki eyvanların kesintisiz olarak orta sofa ile birleşmesidir. Orta sofa böylelikle, karnıyarık plân tipine de güçlü referanslar verir. Özellikle giriş holü tavan plânındaki kirişli döşemenin yönü, kara ve deniz eyvanlarını orta sofa ile üçüncü boyutta mekânsal olarak birleştirir. Böylelikle, ana giriş, Boğaziçi ile kesintisiz olarak bütünleşmektedir.

\section{Salonun Kuruluşu}

Arkitekt dergisinde, Akademi'nin yeni binaya kavuşması ile ilgili yazıda kullanılan plânlarda, üst kat orta sofasının, deniz ve kara cephesindeki eyvanlar da mekâna katılarak haçvarî plânlı olarak çözümlendiği görülmektedir. Bu plânlama anlayışı, mimarların binanın programına getirdikleri yorumun bir sonucudur.

Projede büyük sofa bir hol-toplanma alanı ve gerektiğinde toplantı salonu olarak kullanılabilecek esneklikte etüt edilmiştir.

Bu kullanım biçimi, Akademi binasının yangın öncesi mekân kullanımını da sürdürmektedir. Eldem ve Handan, yaptıkları eskizlerde yeni toplantı salonunu, haçvarî planlı üst hol içinde, kalın perdelerle eyvanlardan ayırarak, denize paralel olarak yerleştirmişlerdir (Resim 11, 12, 13). Bu yaklaşım, iki mimarın öğrenciliklerinden beri belleklerinde yer eden, yangın öncesi Akademi binasının toplantı salonunun, haçvarî plân içinde yeniden canlandırılmasıdır. Mimarların,

Arkitekt'de yayınladıkları perspektif çizimlerde görüldüğü gibi, konferans salonunun yeri ve yönü korunmuştur. Eski salonu merdiven holünden ayırmak amaciyla kullanılan koyu renk kalın perdeler (Türkmen, 1993, 16-20), bu kez eyvanlardan gelen 1şı̆̆ dolan aydınlığı kesmek amacıyla kullanılmıştır.

Konferans salonu, Akademi'nin binaya yerleşiminden kısa bir süre sonra düzenlenmiş ve çevre mekânlardan panolarla ayrılan balkonlu bağımsız bir salon olarak çözümlenmiştir. Bu değişiklik 1930 yılına ait fotoğrafta açıkça görülmektedir (Resim $9 b)$.
Resim 9 a-b: Konferans Salonu, 1927 (solda), 1930 (sağda) (Firat, 2008, 48-89) 


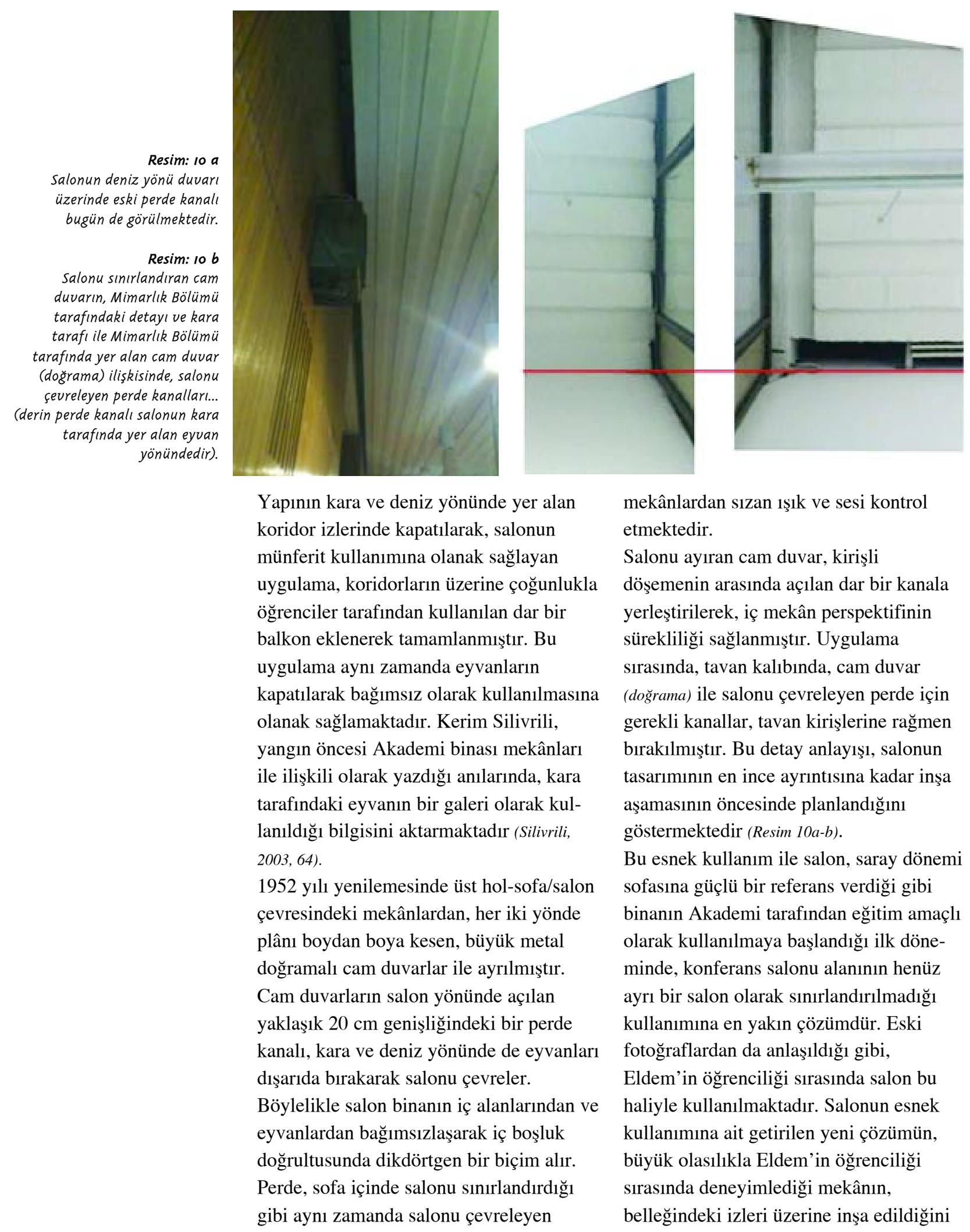




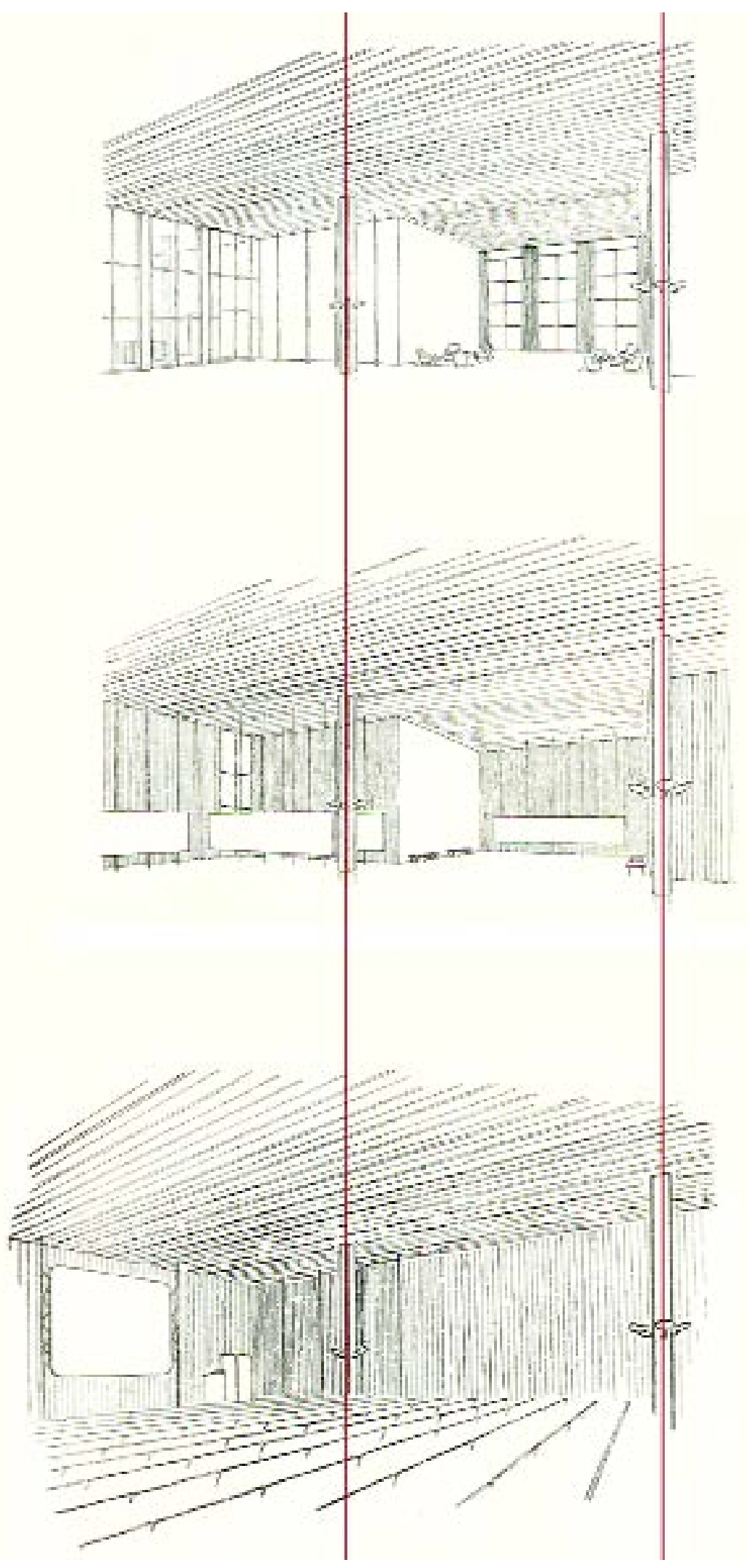

Resim: II $a-b-c$

Salonun Kuruluşu:

Eldem ve Handan'n üst kat sofası kullanım etüdleri. (Eldem ve Handan, 1954, 11-12-13).

\section{Resim: IIa}

Üst Hol / Salon

Eldem ve Handan esnek kullanım imkânı öngördükleri üst hol'ün farklı kullanış biçimlerine ait Arkitekt dergisinde, deniz yönündeki eyvana doğru aynı bakıs ą̧ısını içeren üs perspektif çizimi yayınlamıştır.

Bunlardan ilki yapınin bittiği döneme ait bir fotoğrafla birlikte verilen ve mekanin serbest kullanımına işaret eden çizimdir. Bu çizimde haçvarî salon bir hol olarak temsil edilmiştir. Deniz yönündeki eyvanda iki rahat oturma grubu görülmektedir.

\section{Resim: $\| 6$}

Sergi Holü

ikinci çizim üst holün bir sergi salonu olarak kullanımını ifade eder. Burada dikkat feken unsur yüzeyleri örten perdedir. Salonun Akademi iş mekânına açılan cam duvarları ve deniz yönünde yer alan duvar yüzeyleri ile eyvan cephesindeki pencereler bütünsel bir etki veren perde kullanılarak kapatılmıştır. sergileme boyutu insan ölsülerine yakın tutulmustur.

Resim: IIC

Konferans Salonu

Salonun ü̧̧ӥncü kullanımı konferans amaçlıdır.

22 Sayı 13, 2012 


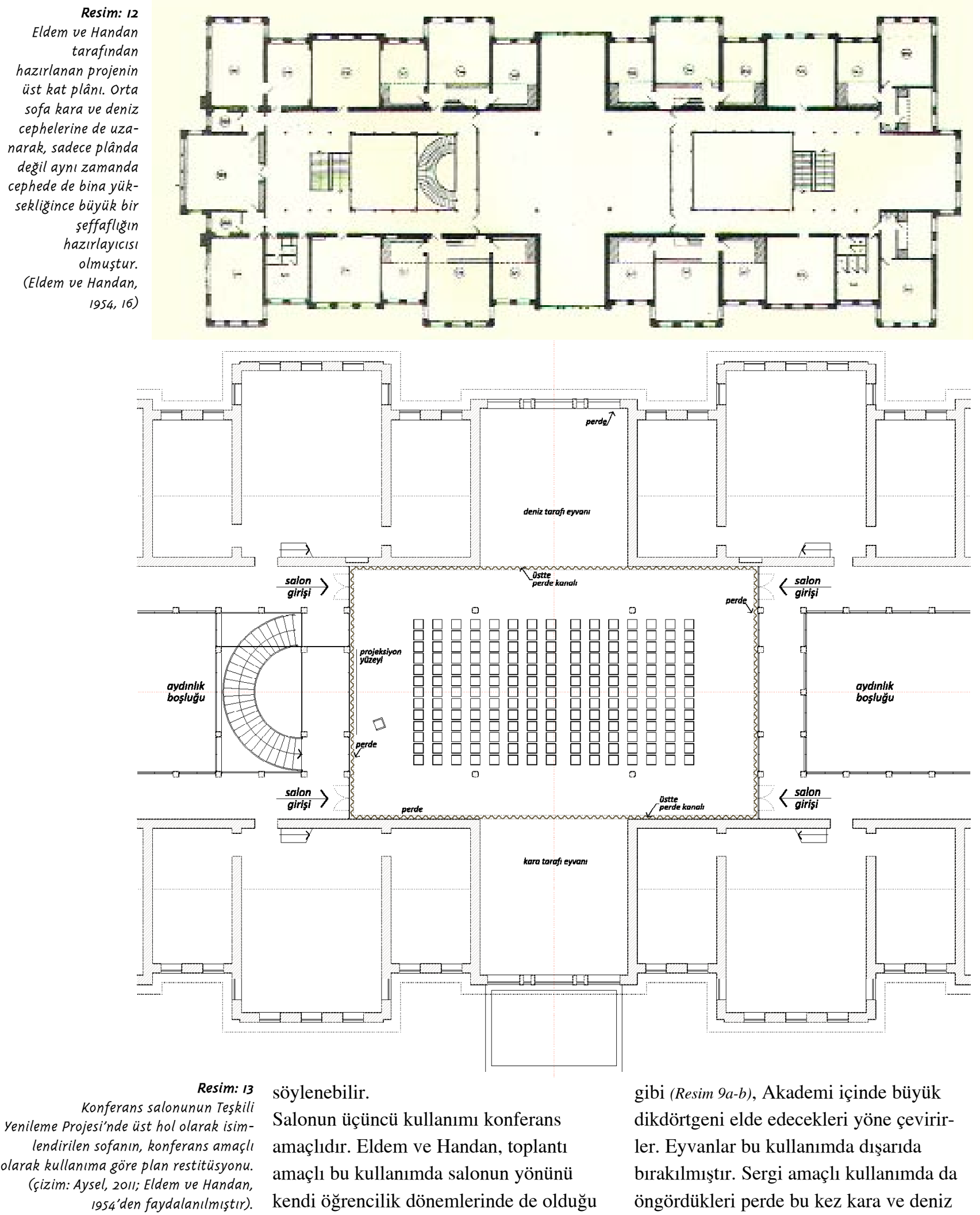


yönündeki duvarlar üzerinden devam ettirilerek eyvanları da örtmekte aynı zamanda akustik destek sağlamaktadır.

Projeksiyon yüzeyi salonun Resim Bölümü yönündeki cam duvar önünde, sergi taşıyıcıları gibi döşeme ve duvara bağlanmış zarif taşıyıcılara asılmıştır. Salon bu çözümüyle Akademi'nin binaya ilk olarak girdiğinde konferans salonu olarak kullandığı üst sofaya referans verir. Müelliflerden bu dönemi yaşayan ise 1924-28 yılları arasında Sanayi-i Nefise Mektebinin öğrencisi olan Eldem'dir. Handan'ın (1933-38) öğrenciliğinde ise Konferans Salonu üst sofa içinde panolarla sınırlandırılarak yeniden inşa edilmiş durumundadır (Resim 9b).

\section{Ortam:}

1960’lı yıllarda Akademi kültürel etkinliklerin merkezi durumundadır. Akademi Müdürü Asım Mutlu²ı ve yönetim ekibinin gayreti ile giriş holü önemli ulusal ve uluslar arası sergilere ev sahipliği yaparken, Eldem ve Handan'ın “üst hol” olarak adlandırdıkları merkezi sofa, bu dönemde yeniden düzenlenerek, konferans, dinleti ve gösterilere sıklıkla ev sahipliği yapmaya başlar (Suher, 2011; Demir, 2011; Şekeroğlu, 2003, 108-115). İtalya, Fransa, Almanya, İngiltere Avusturya gibi ülkelerin elçilik, konsolosluk ve kültür ataşelikleri ile kurulan işbirlikleri Akademi sanat yaşamına da yansımıştır. Asım Mutlu, müdürlüğü döneminde Akademi'nin bir sanat merkezi durumuna gelmesine ilişkin şunları söylemektedir:

“... Ve Akademi, halkımızın sanat zevkini yücelten önemli bir sanat ve kültür merkezi haline geldi. Salonlarımız, yerli, yabancı sanatçıların arka arkaya açılan sergileri ile hiç boş kalmıyor. Haftanın en az iki günü düzenlenen konferans ve konserlerde, yerli yabancı çok değerli sanatçılar ve fikir adamları, aydın bir topluluk karşısında sahneye ve kürsüye çıkıyorlard1." (2003, 74-75)

Başlangıcından beri çok amaçlı olarak kullanılan salonun, akustik sorununu, bina içi bağlantıları da çözebilecek biçimde çözümlemek amacıyla, yeni bir düzenleme yapılması, Asım Mutlu'nun müdürlüğü döneminde gündeme gelmiş, Mimarlık Bölüm Başkanı Utarit İzgi’den bu konuda bir çalışma istenmiştir. Asım Mutlu, müdürlük dönemine ilişkin bir metinde salonla ilgili gelişmeyi şu sözlerle aktarır: "Binamızın üst sofasını yan mekânları da içine alarak büyüyebilen bir salon haline getirerek, burada konferanslar ve konserler düzenlemeye karar verdik." (2003, 74-75)

7 Mayıs 1964 Perşembe günü Akademi'de yapılan müdür seçiminde ikinci defa seçilen Asım Mutlu konuşmasında bir önceki dönemi ile ilgili bilgiler arasında yenilenen mekânlara da yer verir: "Senelerce eksik olarak içinde çalıştığımız Akademi binasının konferans salonu, kütüphanesi [eski senato odas1] ve dershanelerinin [201-202-203 no'lu amfiler] tamamlanmasına imkân hâsıl oldu." (1964)

Asım Mutlu, 1965-66 Öğretim Yı1ı açılış konuşmasında, rakamlarla Akademi'nin ev sahipliği yaptı̆̆ı, giriş holü ve konferans salonunda gerçekleştirilen etkinliklerle ilgili bilgi verir. Burada özellikle konferans salonunun çok amaçlı kullanımı dikkat çekmektedir.

"Akademililerle sanatseverleri yaklaştırıcı ve onlara yararlı kültür faaliyetlerimiz çerçevesi içinde geçen yıl Akademi'de 14 sergi açılmış, 17 konser, 3 tiyatro temsili, 18 konferans verilmiştir. Ayrıca öğrencilerimizin kurduğu Klüp Sinema 7, 21 tanesi Türkiye'de daha evvel gösterilmemiş olanlarla beraber 44 film göstermiş ve sinema konusunda açık oturumlar tertip etmiştir.” $(1966,60)$
$2 \mathbf{I}_{\text {Akademi müdürlerinden Nijad Sirel'in }}$ 1959 yılında vefatı üzerine, Akademi ögretmenleri genel kurulu tarafindan iki müdür adayı seçilip Bakanlığa bildirilmiş, Bakanlık adaylardan Asım Mutlu'yu müdürlüğe tayin etmiştir. Mutlu, 29 Ağustos 1959 günü başladığı görevini, 6 Haziran 1966 günü Hüseyin Gezer'e devretmiştir. (Cezar, 1973) 


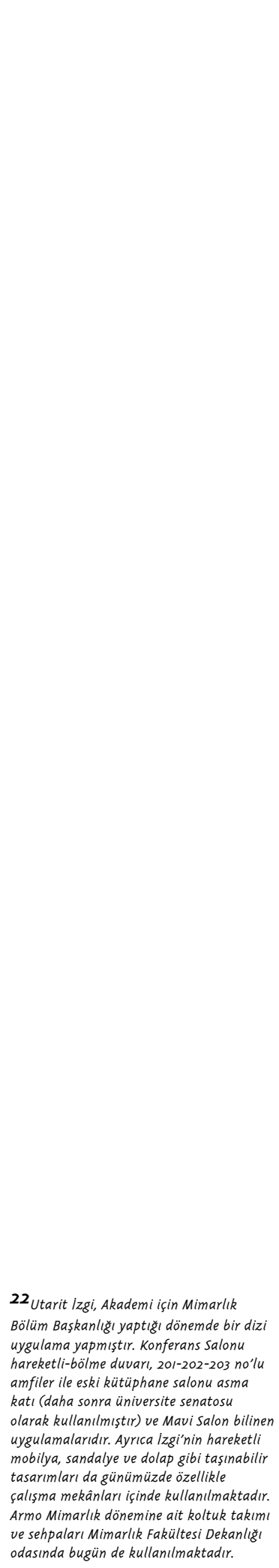

Ayrıca bu dönemde sürekli etkinlikler arasında, Kulüp Sinema 7'nin haftada iki gün düzenlediği film gösterimlerinin yanısıra perşembe günleri Adnan Çoker tarafından plâk ve bantlarla caz müziğinden örnekler verilmiş ve bu müziğin gelişiminde rol oynayan önemli sanatçılar tanıtılmıştır (Akademi 2, 1965). 1968 öğrenci olaylarına dek konferans salonu cuma akşamları çaylı dans partilerine de ev sahipliği yapmayı sürdürmüştür. Eğitim programı içindeki rolünün bir parçası olarak, Mimarlık Bölümü diploma değerlendirme jürileri yapıldığı gibi bir dönem jimnastik salonu olarak dahi kullanılmıştır (Anılanmert, 2003, 253-265).

1965 y1lı etkinliklerinin bilgilerinin yer aldığ 1 Akademi dergisinde Bülent Özer tarafından verilen bir konferansa ait bilgilerde yer alan "Akademimiz konferans ve sinema salonlarında" (Akademi 5, 1965, 66) ifadesi de salonun o yıllardaki kullanım şekli ve yoğunluğu ile ilgili bilgi içermektedir.

\section{Tasarim}

Merkezi sofa/salon kısa bir süre yapıldı̆̆ 1 koşulların esnekliğinde kalacak, daha sonra Utarit İzgi'nin yaratıcı çözümüyle ana karakterini olabildiğince koruyarak, farklı kullanımlara yanıt verecek biçimde düzenlenecektir.22 Toplantı sırasında kanatlar arasındaki ilişkinin sağlanabilmesi ve mekânın mahremiyetinin korunabilmesi için İzgi, kara tarafında yer alan eyvan cephesine ve koridor izindeki karşılığına büyük boyutlu, 630/520 cm ölçülerinde iki hareketli duvar yerleştirmiştir. Bu duvarlardan salon tarafında yer alanı, iki zarif kolonu gerisinde yansitma yüzeyi olarak değerlendirilmiştir. Toplantı sırasında, hareketli duvar kapatılarak T plânlı bir salon oluşması sağlanmıştır (Resim 14).

Tasarım, kara ve denizi buluşturan haçvarî sofa karakterini, gerektiğinde açılan hareketli duvarlar ile sürdürmeyi ilke edinmiştir.

Son 27 yılına tanık olduğum bu süreçte, binaya ne yazık ki ilk tasarımın ilke, ölçü ve değerlerini anlamaya ve sürdürmeye çalışmayan çok fazla ekleme ve değişiklik yapıldı. Bunların tümü için tek bir gerekçe gösterildi: kalabalıklaşma... Ancak içinde bulunduğumuz binanın niteliği göz önünde bulundurulduğunda yapılan özensiz ve niteliksiz uygulamaları açıklamak için kalabalıklaşma ve mekân yetersizliği gibi sorunlar bahane edil(e)memelidir. Bu konuda, Utarit İzgi Akademi'nin bugünkü mekânını şu sözlerle yorumluyor;

"Biz mimarlık eğitiminin yapıldı̆̆ı yerde yapının kendini bu hale sokarsak, bakamazsak, koruyamazsak, kötü ilaveler yaparsak ve özünde de kötü olursa bu bina etkisi kötü olur..." $(2003,86)$ Ercüment Tarcan Hoca, Akademi binasının aydınlıklarının doldurulması ile ilgili kendisine yöneltilen soruya, Akademi'nin yetiştirdiği tüm hocaların düşünmesi gereken bir yanıt verir; "Maalesef o avlular doldurulmayacaktı. Sedad Bey'in o hususta etüdü vardı. O avlular ciğerleri tabii ki Akademi'nin. Yani 1şık. Bırakın 1şı ğı ciğerleri. Hava alacak oradan. Nasil doldururlar anlamıyorum. Akademi'de ne kadar mimarlı uygulamalart yapılıyorsa hepsi en kötüsünden oluyor. Mimar yetiştiği halde. $\mathrm{O}$ aydinlıklara dokunmayacaklard1..." (2003, 42).

\section{Uygulama}

Merkezi salonun açılabilir bir konferans salonuna dönüşmesi sırasında, daha önce de dikkat çekildiği gibi İzgi, hocaları olan Eldem ve Handan'ın binasına en az müdahale ile dokunarak çözüm aramış, ancak 


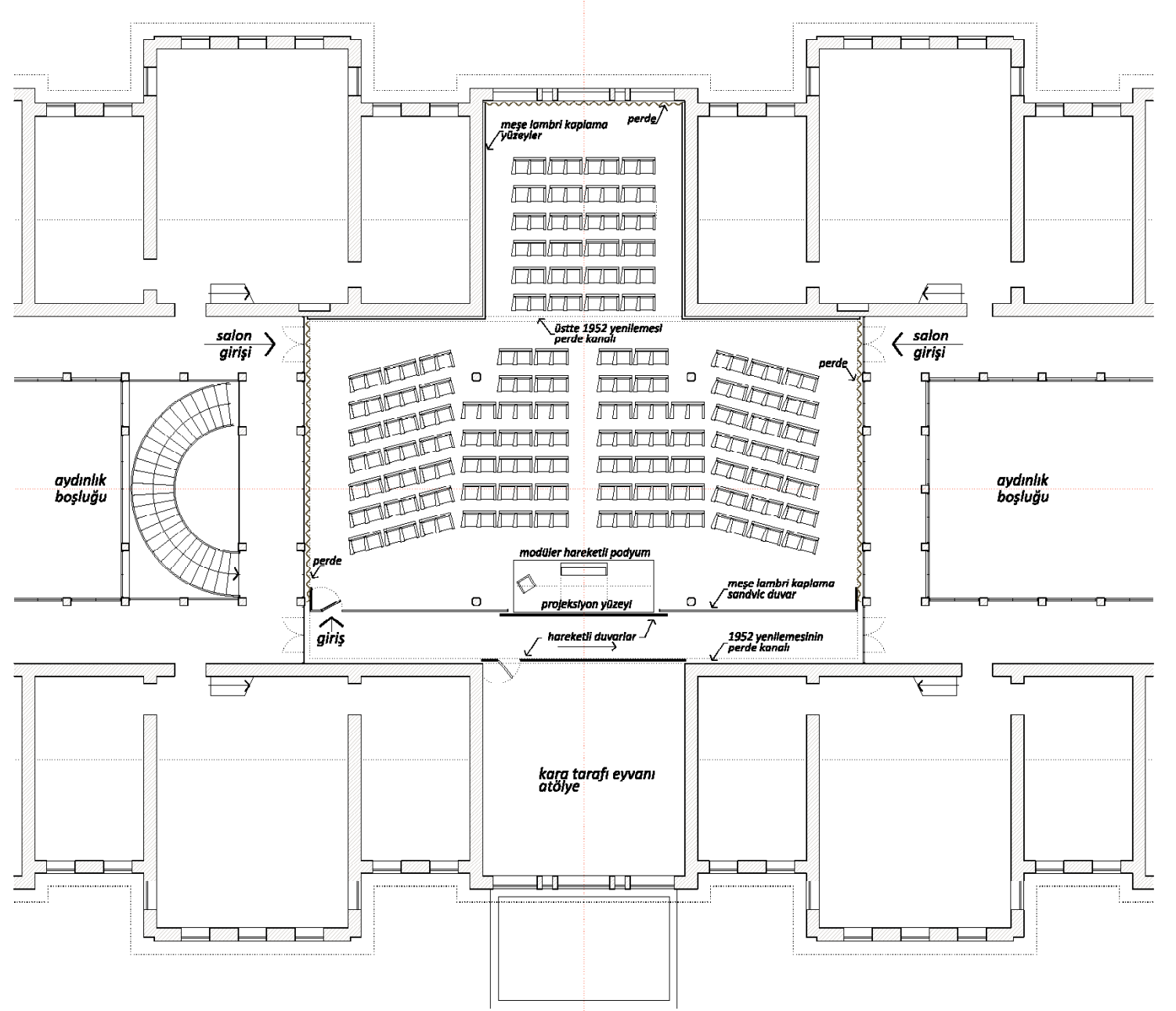

müelliflerin planladıkları salonun şemasını değiştirerek, projeksiyon perdesini kara yönündeki eyvan tarafına almıştır. Uygulamanın yapıldığı dönemde her iki müellif hoca da eğitim kadrosundaki görevlerini sürdürdüklerinden, proje ve uygulama aşamasında tasarımın onaylarına sunulmuş, görüşlerinin ve rızalarının alınmış olması gerekir. Eldem'in sonraki yıllarda Akademi binası ve çevresine yaptığı proje ve uygulamalar onun 'sarayın mimarı' olduğunu tartışmasız kılar. Çözümün, Asım Mutlu'nun uzlaşmacı-politik kimliğinde gizli olduğu düşüncesi kanaatimce ağır basmaktadır.

Bir başka önemli etken, Nazımî Yaver
Yenal'ın salon için tasarlanmış olan kolçaklı sıralardır. ${ }^{23}$ Eldem ve Handan tasarımında esnek olarak kullanılması planlanan mekân, ağır ve masif ahşap sıraların yerleştirilmesi ile kolaylıkla değiştirilemez bir mekân kullanımına kavuşmuştur.

1952 yenileme projesinde çok amaçlı olarak kullanılabilen üst sofanın, özüne aykırı görülen yeni tasarım, binanın mekân kullanımının zaman içinde, Eldem ve Handan'ın tasarladığı biçimde gerçekleşmemesinin de bir sonucudur. Projede üst katta hocaların oda ve atölyelerini, Güzel Sanatlar ve Mimarlık bölümleri olarak iki ayrı kanatta toplayan mimarlar, salonu ortak bir toplanma holü olarak, her

\footnotetext{
23 Bu konuda kesin bir belge-bilgi olmamasına karşın, belleklerde Hoca'nın adı yer etmiştir. Ahşap siraların Akademi'nin yangin öncesi fotoğraflarında olmaması ve arşivde ulaşabildiğimiz fotoğraflarda, konferans salonunun yeni düzenlemesi içinde görünmesi, bu tasarımın bir parçası olduğu düsüncesini geliştirmektedir.
} 
$\mathbf{2 4}$ Bu duvarların yapının diğer unsurlarından bağımsız olarak çözümlenmesinde Mies van der Rohe'nin Tugendhat Villasinda (Brno, Çekoslavakya, 1930) ve Barselona Pavyonundaki (1929) bölme duvarlarınin benzeri bir tasarım anlayıs izlenmektedir.

25 Perde kullanımı, cephenin büyük cam yüzeylerle kurulduğu modern mimarlık örneklerinden Mies van der Rohe'nin Farnsworth Evi (Illinois, 1951)'ne de referans verir. Eldem ve Handan'In Akademi üst holündeki cam duvar ve perde uygulaması bir yil ara ile 1952 yilidir.

$\mathbf{2 6}$ Le Corbusier'in Marsilya (1947-52) ve Nantes konut bloklarinda (1952) her biri yaklaşık 1,83 m genişliğindeki iki çocuk odasinı cephe yönünde istenildiğinde açlabilen sürme duvar ile birlestirmesi sınırlı olanaklara sahip mekânların esnek kullanıminda duvarı önemli bir rolü olduğunu göstermektedir.

$\mathbf{2 7}$ Uygulama, y. Mimar i. Orhan

Demirpençe (GSA, 1944 mezunu) tarafindan yapılmıştır. (Suher, 2011; Ünal, 20II) iki kanadı ayıran/birleştiren bir unsur olarak değerlendirmişlerdir. Ancak mekânların kullanımının zamanla projedeki düşüncenin tersine her iki kanada yayılması, İzgi'nin salonu çözümlerken, konferans sırasında da işleyebilecek bir yatay bağlantıyı kurmasını zorunlu kılmış olmalıdir.

Uygulama sırasında salonun deniz yönünde yer alan L şeklindeki iki sağır duvar ile kara tarafında hareketli duvarın iki yanındaki duvarlar, akustik amaçlı olarak düşey yönde meşe lambri ile kaplanmıştır. Lambri yüzey, salonu diğer mekânlardan ayıran metal doğramaya temas etmeden önce bitirilmiştir. ${ }^{24}$ Salonun Akademi iç mekânı ile arasındaki büyük cam yüzey, açık kahverengi kalın bir kadife perde ile gerektiğinde kapatılabilir olarak plânlanmıştır. Kalın perde, akustik sorunları olabildiğince çözümlediği gibi, aynı zamanda toplantılar sırasında konuşmacıyı rahatsız etmeden girip çıkma olanağını da sağlamıştır. Doğrama ile arka duvarlara kaplanan lambri arasındaki bırakılan boşluğu perde kapanmaktadır. Bu çözüm, salonun sofa içinde sınırlandırıldı ğı anlayışın sürdürülmesidir. Büyük cam yüzeylerin gerektiğinde perdeler ile çevreye kapanabilmesi ile salon çevre mekânlardan ayrılarak mahremiyeti sağlanabilmektedir. 25

İzgi ve Suher tasarımının karşılaştığı zorluk, hocaları Eldem ve Handan'1n,

Akademi'nin merkezi salonu olarak yorumladıkları haçvarî salonunun ana karakterini koruyarak, farklı etkinliklere yönelik esnek bir çözüm arayışıdır.

Yukarıda bahsedilen hareketli duvarlar ${ }^{26}$, gerektiğinde kenara çekilerek açılacak ve kara tarafındaki eyvan ile salon arasında bırakılan koridor ana mekâna katılarak haçvarî büyük salonu tekrar kuracaktır. Akademi konferans salonu hareketli duvarı, gerek konumu gerekse de ölçüleri bakımından bölme duvarı örnekleri ile k1yaslanamaz. Hareketli duvarlar 40x40 mm kutu demir 1zgara karkas üzerine ahşap pano kaplanarak yapılan sandviç panellerdir. ${ }^{27}$ Duvarlar mevcut yapı ile döşeme ve tavan dışında bir ilişki kurmaz. Daha önce Eldem ve Handan tarafından yapılan ve gerektiğinde salonun kapatılmasına olanak veren metal doğramalar işlevleri bütünüyle korunamasa da yerinde bırakılmışlardır. Bu zarif dokunuş, panolar arasındaki çalışma mesafelerini kapatmaya çalışmayan, mevcut doğrama ile perde duvarlar arasındaki açıklığ 1 , kalın kadife perdelerin toplanarak kapatmasını öngören bir tasarımın sonucudur (Resim 15a-b).

Salonun esnek kullanımına uygun olarak, kürsünün bulunduğu sahne/podyum, 100x180x32 cm ölçülerinde 6 adet halı kaplı modüler platformun yan yana getirilmesi ile oluşturulmuştur. Podyum, salonunun haçvari plana dönüştürülmesi gerektiği zamanlarda toplanarak kaldırılabilmektedir. Çay partileri, gösteriler, müzikli toplantılarda podyum, kara tarafındaki eyvanın içine kurularak orkestra için ayrı bir alan yaratılmasına olanak sağlamaktadır.

Sahne oyunlarının sergilenmesinde, podyum kaldırılarak hareketli duvarlar açılır, kara tarafında yer alan eyvan bu kez sahne gerisi görevi üstlenir.

İzgi'nin konferans salonu bölme duvarları tasarımı öncesinde süreci etkileyen bazı deneyimlerden bahsetmek gerekir. Bunlardan ilki öğrenciliğinde Eldem'in kendisinden yapmasını istediği bir bölme duvarıdır. Tahsin Günel (Ilıcak Yalısı olarak da bilinmektedir) Yalısı'nda istenen bir bölme duvarı işini Eldem, kendi gözetiminde genç İzgi'ye vermiştir. Bu yalnızca bir çizim işi değil, detaylamauygulama ve maliyeti de içeren bir 


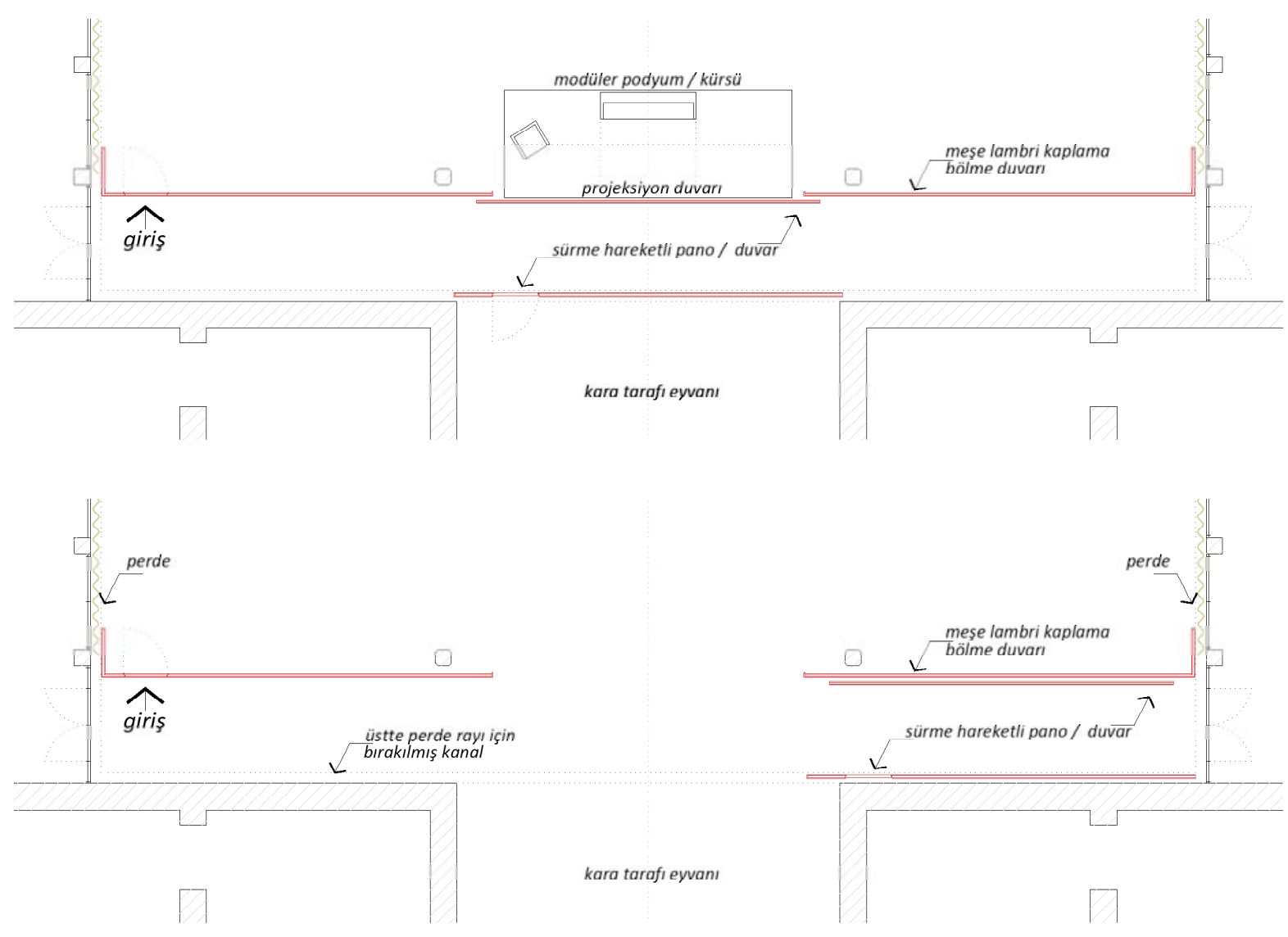

çalışmadır.

Tasarım ile teknoloji ilişkisini uygulamalarında ustaca buluşturan Utarit İzgi, henüz Türk mimarlığının yeni tanıştığ duvar teknolojilerini, perde duvar ve serbest duvar kavramları ile ilgili görüş ve örnekleri değerlendiren makalesinde, bir yapı elemanı olarak duvar eylemlerini üç gruba ayırır (1964, 12-14);

- Statik: taşıma, taşınma

- Bölme: sınırlama, düzenleme

- Koruma: izolasyon ve emniyet Ona göre duvarın taşıyıcı niteliğinin değişmesi yapı teknolojisinin önemli bir aşamasıdır. Akademi konferans salonu tasarımına eklenen bölme duvarının da yapının statik bir parçası olmaması, İzgi'ye duvarı serbest çözümleme olanağı vermektedir. Duvar, hafif bir bölme elemanı olarak ele alınabilecektir.
Duvarın gelişmesindeki en son kademeyi perde-duvar veya serbest duvar teşkil eder. $\mathrm{Bu}$ sistemde duvarın önemini kaybetmesine, bölünmesine hatta çözülmesine, parçalanmasına doğru atılan ilk adımları görmek kabildir. (İzgi, 1964, 12-14)

Akademi'de konferans salonunu sınırlayan ve esnek kullanım olanağını sağlayan çözümün öncesinde İzgi'nin, 1958 yılında Muhlis Türkmen, Hamdi Şensoy ve İlhan Türegün ile birlikte tasarlayarak inşa ettikleri Brüksel Uluslararası Sergisi Türk Pavyonu deneyimi bir başlangıç oluşturmaktadir.

İzgi'nin Akademi konferans salonu uygulaması ile yakın dönemde gerçekleştirdiği bir diğer uygulaması, Pendik'de Temenye Koyu kıyısında, Asım Mutlu ve Esad Suher ile birlikte M3 Mimarlar ${ }^{28}$ grubu
Resim: 15a-b Utarit Izgi ve Esad Suher'in konferans salonu 1962 yenilemesinde, hafif duvarlar ile bölünen salonun, hareketli duvarın kapalı ve af̧ı durumları. (çizim: Aysel, 20II)

$28 \mid$ sayı 13, 2012 
29 Izgi'nin (M3 Mimarlar Grubu) brütalist mimarlık akımınin etkin olduğu bir dönemde tasarladığı bu yapinin cephe panolarinin benzer bir yorumu brüt beton ve ahşap sandvi६ pano kullanımı ile Louis Kahn'ın Salk Enstitüsü (La Jolla, California, 1959-1965) binası dı̧ cephesinde de görülür.

Kunt Yalısı, ne yazık ki $80^{\prime} l i$ yillarda baslayan sahil yolu projesinin bir sonucu olarak kiyidan yaklaşık $300 \mathrm{~m}$ işeride kalmıştır. Kıyı ile bağının kopmasi, yalının kısa süre içinde birkaç kez el değistirmesine ve özgün yapısının da bu süreç içinde yavaş yavas bozulmasina neden olmustur.

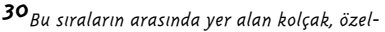
likle konser, dinleti ve film gösterimlerinde daha çok izleyicinin salonu kullanabilmesi için kesilerek, sıralar üç kişilik hale getirilmiştir. siraların orijinal durumda çok az örneği bulunmaktadir.

$3{ }^{2}$ Türk Film Arşivi'nin Devlet Güzel Sanatlar Akademisi'ne bağlı bir arşivleme, araştırma yayın ve eğitim kurumu olması, 8 Ağustos 1968 'de Akademi Temsilciler Kurulu'nda kabul edilerek onaylandı. 1969'da "Istanbul Devlet Güzel Sanatlar Akademisi Film Arşivi" yönetmeliği resmi gazetede yayınlandı. Bilim-sanat kültür kurumu haline gelen Film Arşivi 1975 yılında "Sinema Televizyon Enstitüsü" adını aldı. (Sinema-TV Bölümü; http://mimarsinanarts.com, 16 Ekim 2011)

32 salon ders amaçlı olarak kurumda mekan

sorunları çıkmaya başladıktan sonra kullanılmiştir. 1960'lı yillarda yalnizca toplantı ve gösterim amaçlı olarak kullanılmıstır. (Demir, 20II)

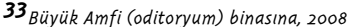
ylında Sedad Hakkı Eldem'in 100. Doğum yılı etkinlikleri sirasında hocanın adı verilmiştir. Günümüzde 'Sedad Hakkı Eldem Oditoryumu' olarak anılmaktadır. olarak tasarladıkları Kunt Yalısıdır29

(Pendik, 1964). Her iki tasarım, düşünsel benzerliğin yanı sıra aynı zamanda malzeme ve uygulamaya yönelik benzer, ortak çözümler içermektedir. İzgi'nin Konferans Salonu çözümlemesinde kullandığı yüzen sabit duvarlar ile Kunt Yalısının cephe panoları aynı tasarım anlayışı ve detay çözümünün ürünüdür. Tüm bu uygulamalar, İzgi mimarlığının teknoloji ile tasarım arasındaki işbirliğinin bundan sonra izleyeceği yolun habercisidir.

Konferans Salonu, üniversiteye bir büyük salon yapılana kadar tüm önemli toplantılara ev sahipliği yapmış, ayrıca ilerleyen dönemde bölümler arası ortak dersler için bir büyük sınıf olarak kullanılmıştır. Masif ahşap iki kişilik yazma kolçaklı salon sıraları ${ }^{30}$, zarif aydınlatma elemanları, köşede yer alan kuyruklu piyano, kalın kadife perdeler ve akustik ahşap duvar panelleri ile Konferans Salonu her zaman Akademi için itibarlı bir mekân ve sanat etkinliklerinin buluşma odağı olarak var olmuştur. Yetmişli yılların ilk yarısında Türkiye'nin ilk sinema-TV enstitüsünün' DGSA bünyesinde kurulmasının ardından, salona bir sinema makinesinin ve odasının eklenmesi, ne yazık ki zaman içinde salonun deniz yönünün kapatılmasına neden olacaktır. İlk zamanlarda deniz tarafındaki eyvan içinde bir perdenin gerisine yerleştirilen film makinesi için daha sonra kalıcı bir düzen geliştirilecek ve deniz yönündeki eyvan içinde, meşe lambrilerin çevrelediği bir oda yapılacaktır. Bu düzenleme ile salonun haçvarî ve merkezi karakteri bozulmamış gibi görünse de deniz ile bağı kopmuş ve tasarım ilkesi önemli ölçüde bozulmuştur.

Salonun haçvarî etkisini bozan bir diğer önemli gelişme ise kara tarafında yer alan eyvanın Vitray Atölyesi olarak

kullanılması ve bir asma kat yapılmasıdır. 1990'lı yıllarda yapılan asma kattan sonra orta sofanın esnek kullanımına olanak veren hareketli panolar ise artık hiç açılmamak üzere belleklerdeki yerini alacaktır. Ne yazık ki sonradan yapılan uygulamalarda bu panoların açıldı ğı da unutulmuş ya da ihmal edilmiş, kablo kanalları ve süpürgeliklerle bulundukları yere sabitlenmişlerdir.

Salon, bugünkü biçim ve boyutlarına, 90'l1 yılların sonunda sinema makine dairesi olarak kullanılan kısmın, salon yönünde büyütülerek bağımsız bir oda halinde Grafik Bölümü'ne verilmesi ile ulaşmıştır. Konferans salonundan kolaylıkla vazgeçilebilmesi ve küçük ihtiyaçlar için büyük bir düşüncenin ve kurum tarihinde de önemli bir mekanın tüketilerek, yalnızca ortak derslerin yapıldı ğ $1^{32}$ bir büyük sınıfa dönüştürülmesinde, Akademi bahçesinde Sedad Hakkı Eldem tarafından projelendirilen 'Büyük Amfi' (oditoryum) ${ }^{33}$ binasının yapılmasının ve etkinliklerin adresinin değiştirilmesinin etkisi olduğu kaçınılmazdır. Sinema makinelerinin yeni yapılan oditoryum binasına taşınması, konferans salonuna tekrar eyvanı ile buluşması şansı vermesine karşın, ne yazık ki bu fırsat değerlendiril(e)memiş ve her iki eyvan da tüm yöneticilerin söz birliği etmişcesine dile getirdikleri 'mekan sorununa' çözüm bulmak amaciyla kapatılmıştır.

Binaların tasarımının temel prensiplerine aykırı duran sert dokunuşlar, ardından yapılacak olan ve bizleri bugünkü mekânlara taşıyan değişikliklerin de öncüleridir. Akademi kurulduğu günden beri var olan mekân sorunu, farklı dönemlerde Akademi müdür, başkan ve rektörleri tarafından her ders yılının açılış konuşmaları içinde 

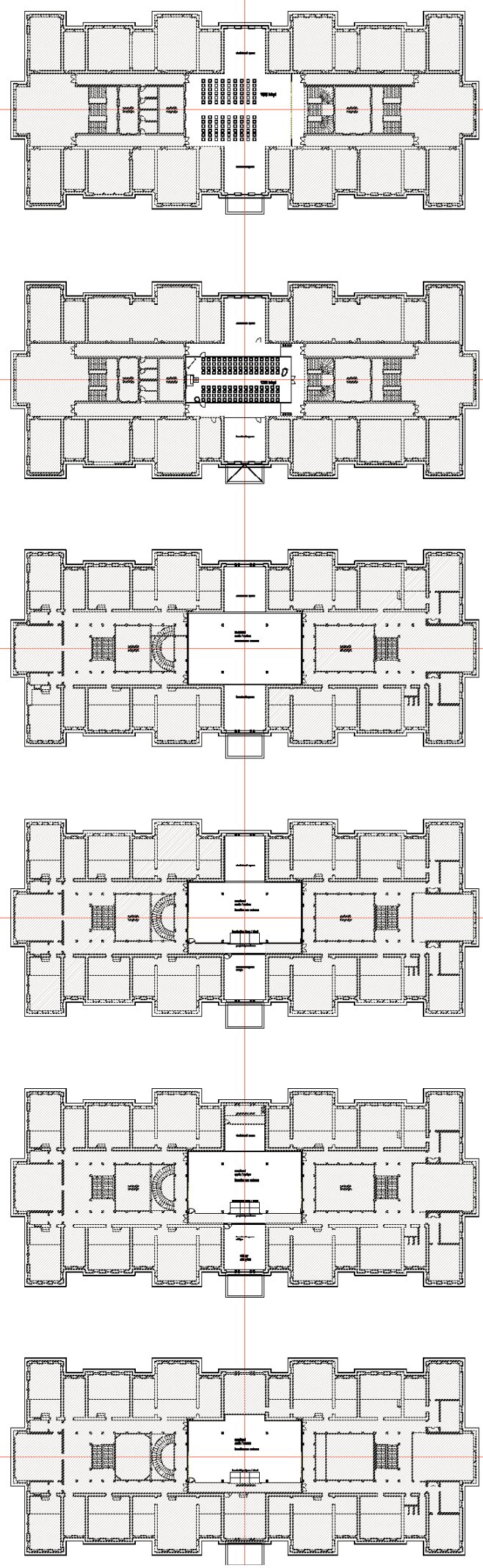

\section{0+ Derslik/Salon}

Doksanlı yıllarda sinema makinesi odasının kapattığı eyvan, salon yönünde büyütülerek Grafik Bölümü’ne derslik olarak verilmiş, böylelikle salonun esnek kullanımı sonlandırılmıştır. Ne yazık ki salon giderek daralmış ve bugünkü ölçülerine ulaşmıştır.

\section{Sofa/Salon} , binaya ilk yerleşildiğinde Projeksiyon Beşiktaş yönündeki aydınlık

\section{Salon} konferans salonu biçimine dönüştürülen üst sofadır. Ahşap panolarla bölünen sofanın eyvanları da bu dönemde atölyeye dönüştürülmüştür.

\section{Sofa/Salon}

Eldem ve Handan'ın belleklerindeki ni de bozmadan getirdikleri çözüm, konferans sırasında eyvanların ve okulun mekanlarından salonu ayıran cam ilkesine dayanmaktadır.

\section{Salon/Sofa}

getirilen çözüm, Akademi'nin o dönemde kültür ve sanat merkezine dönüşmesinin imkanı sağlamaktadır. Ancak bu tasarımda Eldem ve Handan tasarımı gibi isa bir süre işlerliğini sürdürmüştür. önce eyvanların atölyelere dönüşmesine, sonra esnek kullanımlı salonun bölümler arası dersler içinde kullanılması ve sürekli konferans salonu biçiminde kapalı olarak değerlendirilmesini zorunlu kılmıştır.
Resim: 16

Konferans salonunun zamana bağlı mekansal değişimi (çizim ve yorum: Aysel, 2011) Resim: 17

Konferans salonunun zamana bağlı mekansal değişimi. (yorum: Aysel, 2011; fizim: Efe Emre Usman) 

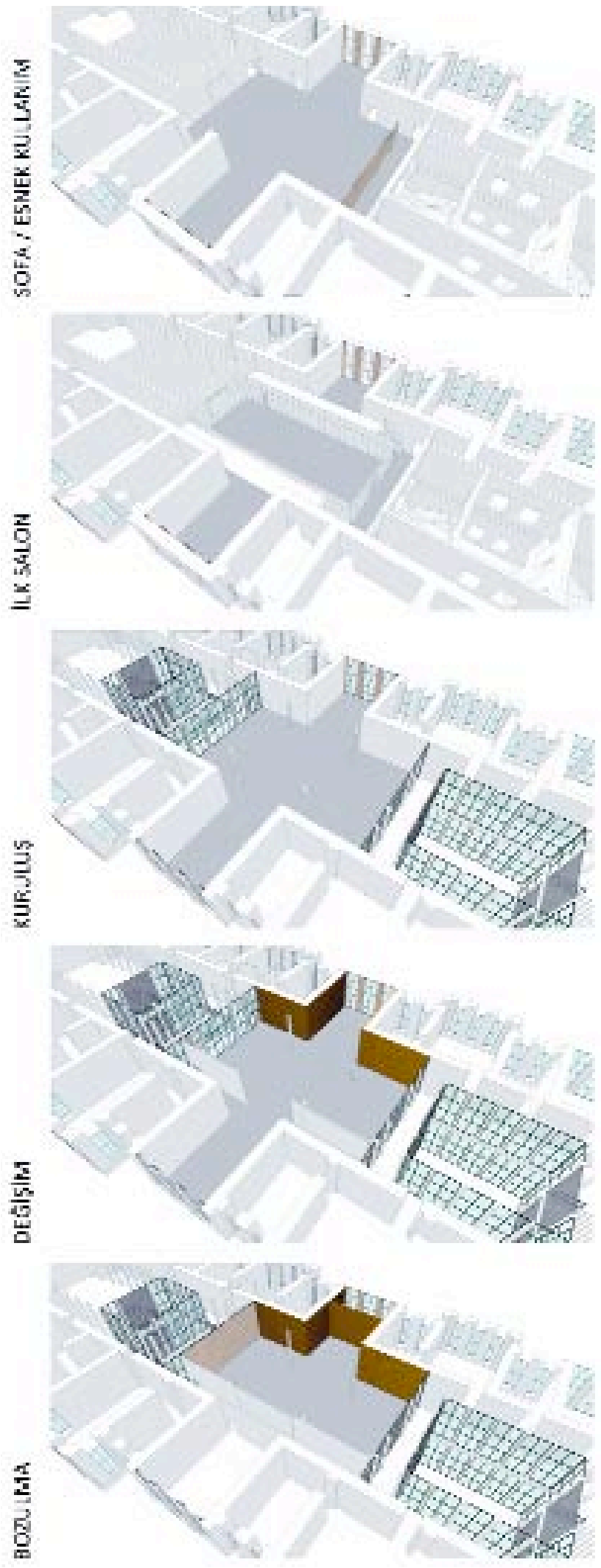
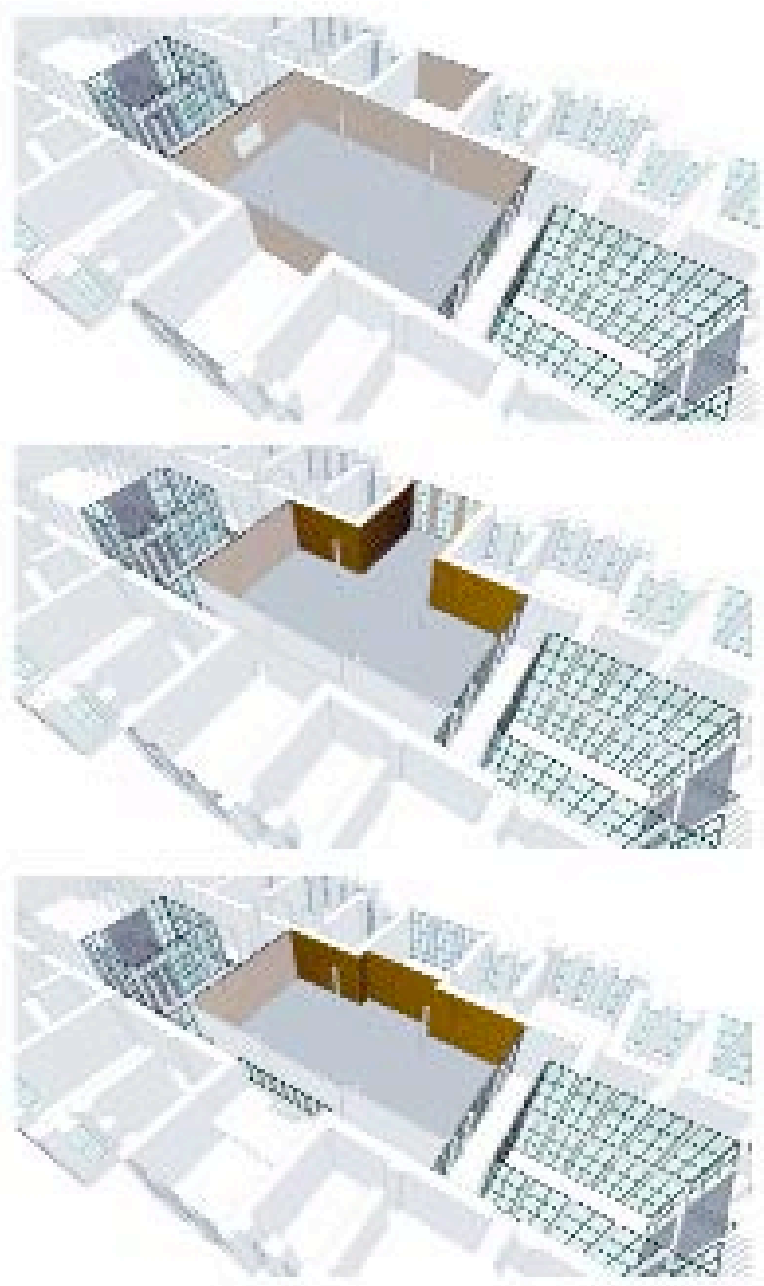

$\operatorname{say1} 13,201231$ 
değerlendirilmiş ve yapılan uygulamalar arasında mekân kazanmak(!) önemli bir görev olarak kabul görmüştür.

Ne yazık ki mekân sorunları Akademi'yi tüm dönemlerinde kabuğu içinde gelişmeye zorlamış ve 1952 Cemile Sultan, 1976 Münire Sultan blokları yenileme projelerinde görülen zengin iç mekânlar yalnızca ilk yapıldıkları dönemde kısa bir süre için yaşayabilmişlerdir.

Osman Hamdi Salonu'na açılan aydınlık boşluğunun yeniden açılması ile başlayan, içinde bulunduğumuz günler iyi değerlendirilerek, ülkemiz sosyal ve mimarlık tarihi açısından son derece önemli olan binaların ayıklanması için de fırsat ve imkân yaratılmalıdır.

Konferans salonuna ait Eldem ve Handan'ın ilk eskizleri ve uygulamaları ile birlikte, İzgi ve Suher yenilemesi yapıldıkları yılların mimarlık düşünce ve pratiği ile derin bir ilişki içindedir. (Resim 16, 17) Yenilenme sirasının Konferans salonuna geldiğini düşünerek, titiz bir ayıklama ve yenileme projesi ile eski esnek kullanımının tekrar kazandırılması gerektiği düşüncesindeyim. Günümüzde ve gelecekte, yaşanan ve yaşanacak olan yer sorunlarını bu eşsiz Çifte Saray’ın kalın duvarları içinde çözmeye çalışmadan önce, mekânlara itibarlarını iade edebilme fırsatını yaratmalıyız. Unutmamak gerekir ki köklü kurumlar, mekânları ile özdeşleşir ve anilirlar.

\section{Yazıyı Sedad Hakkı Eldem'in 1966} yılında, binada yapılan renk değişikliklerine istinaden yazdığı uyarı

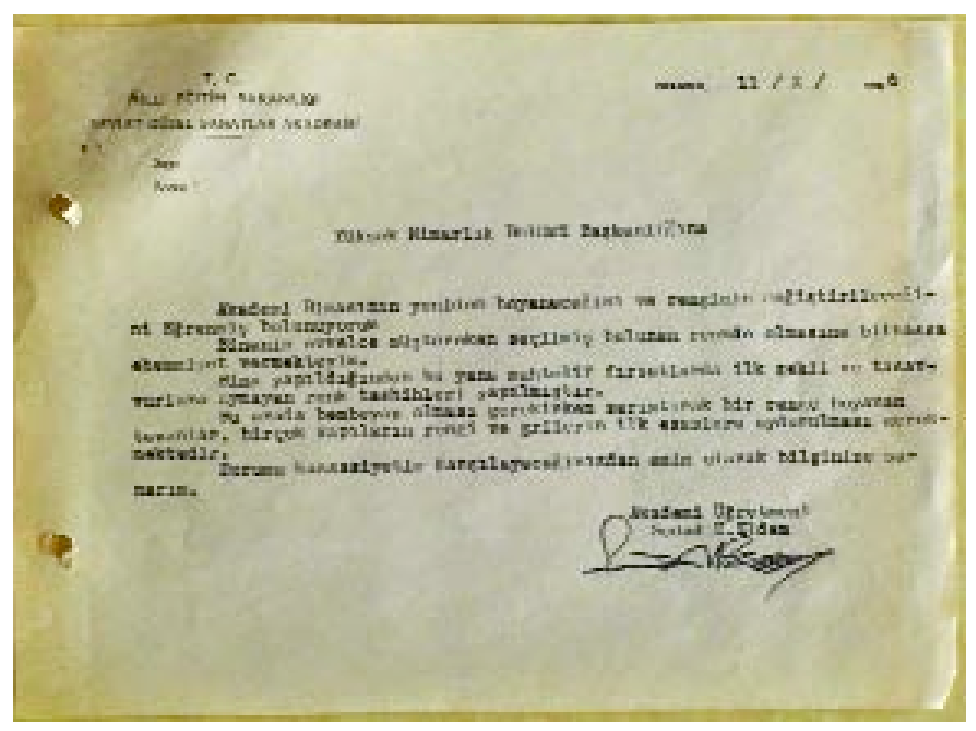

dilekçesi ile bitirelim. Sözkonusu dilekçe, müelliflerin yalnızca kabuk ve biçimi değil aynı zamanda rengi de tasarımın parçası olarak değerlendirdiklerini ve önemsedikResim: 18 Sedad Hakkl Eldem'in 1966 tarihli dilekşesi.

(Yapı Bilgisi Bilim Dalı Arşivi)

lerini göstermektedir. (Resim 18)

Aynı hassasiyeti ve sorumluluğu sonraki kuşakların da göstermesi dileği ile Akademi mekânlarına ait tasarım ve uygulamalarını, düşünce izlerini takip etme fırsatını bulduğum değerli hoca ve ustaları saygıyla anarım

\section{Teșekkür:}

Bu yazının oluşması sırasında;

katkıda bulunan hocalarım Esad Suher, Mete Ünal ve Ataman Demir'e,

konferans salonu ve çevresinin üç boyutlu modelini bilgisayar ortamında hazırlayarak görselleştiren mimar Efe Emre Usman'a teşekkür ederim. 
KAYNAKLAR:

Akademi'de Sanat Olayları. Akademi: Mimarlık ve Sanat: 1-7. Sayılar.

Akın, Günkut. 1990. Asya Merkezi Mekân Geleneği. Ankara: Kültür Bakanlığı Yayınları.

Anılanmert, Oktay. 2003. Akademi'ye Tanıklık: 1 (Güzel Sanatlar Akademisi'ne Bakışlar: Resim ve Heykel) içinde, A. Ö. Gezgin (ed.). İstanbul: Bağlam Yayınları, 251-265

Anılanmert, Beril. 2003. Mimar Sinan Üniversitesi'nin 120. Yılında Seramik Bölümü. Sanat Çevresi (özel s ay1 4): 70-73.

Anonim. 1940. Güzel Sanatlar Akademisi

Anonim. 1991. Mimar Sinan Üniversitesi 108. Yılında (tanıtım kitapçığı)

Aysel, Nezih R. 2004. Mimari Tasarımın Biçimlenmesinde Bir Çevre Faktörü Olarak Su ve Boğaziçi Örneği. Yayımlanmamış doktora tezi. M.S.G.S.Ü. F.B.E

Cezar, Mustafa. 1973. Kuruluşundan Bugüne Akademi. Devlet Güzel Sanatlar Akademisi [1883-1973] 90. Y1l. İstanbul: DGSA Yayını.

Çubuk, Mehmet. 1984. 44 Yılda Prof. M. Ali Handan: Kişiliği, Şehircilikle İlgili Düssünceleri Proje ve Uygulamaları. İstanbul: M.S.Ü. Yayını.

Dora, R. Ruşen. 2000. Selâmlık Köşkü Yeniden Canlanıyor. Sanat Çevresi (259): 24-25.

Eldem, Sedad H. 1954, Türk Evi Plân Tipleri, İstanbul Teknik Üniversitesi.

Eldem, Sedad H. ve HANDAN, Mehmet Ali. 1954. Güze Sanatlar Akademisi. Arkitekt 1-2: 5-17.

Eldem, Sedad H. 1977, Köçeoğlu Yalısı, Bebek. İstanbul: Apa Ofset.

Eldem, Sedad H. 1983. 50 Yillık Meslek Jübilesi. İstanbul: M.S.Ü. 100. Yıldönümü Armağanı.

Eldem, Sedad H. 1995. Boğaziçi Yalıları:1 Rumeli Yakası. İstanbul: Vehbi Koç Vakfi.

Fırat, Kamil (haz.). 2008. Geçmiș Zaman Fotoğrafları: M.S.G.S.Ü.'nin 125. Yılına Armağan. İstanbul: M.S.G.S.Ü. Yayını.

Gülmez, F. Gülşen. 2011, Saray’dan Akademi’ye Sürdürülen Orta Sofa Karakteri: M.S.G.S.Ü. Mimarlık Fakültesi Orta Hol Yenileme Projesi, mimar.ist 41: 16-23.

İzgi, Utarit. 1964. Yapıda Duvar. Akademi, say1 1, İDGSA, s.12-14

İzgi, Utarit. 2003. Akademi'ye Tanıklık: 2 (Güzel Sanatlar Akademisi'ne Bakışlar: Mimarlık) içinde, A. Ö. Gezgin (ed.). İstanbul: Bağlam Yayınları, 7388

Köksal, Aykut. 2009, Tanıklıklar Üzerinden Bir Okulun Mimarlığı. Anlamın Sınırı: Mimarlık, Kent ve Sanat Yazıları 2. İstanbul: Arkeoloji ve Sanat Yayınları, s.239-243.

Küçükerman, Önder. 2005. Bir Sanat Kurumunun 120 Yılı ve Dört Dönemi. Mimar Sinan Güzel Sanatlar Üniversitesi: Bilgi Kataloğu 2005-2006, s.13 29.

Mutlu, Asım. 1964, 1964-65 yılı Açılış Konuşması. Akademi 4: 84-85

Mutlu, Asım. 1966. G.S.A. 1965-66 Ders Y1lı Açılış
Konuşmas1. Akademi 5: 60

Mutlu, Asım. 2003. Akademi Müdürlüğünde Yedi Yıl. Sanat Çevresi (özel sayı 4): 74-75 (ilk yayınlanma Sanat Çevresi 1983 / 53)

Oğuz, Ceylan. 1996. Çifte Saraylar, İstanbul Ansiklopedisi, İstanbul Tarih Vakfı Yayınları. cilt 2:512-513

Özer, Bülent. 2003. Akademi'ye Tanıklık: 2 (Güzel Sanatlar Akademisi'ne Bakışlar: Mimarlık) içinde, A. Ö. Gezgin [ed.]. İstanbul: Bağlam Yayınları, 213222.

Silivrili, Kerim. 2003. 1 Nisan 1948 Akademi Yangınına Dair. Sanat Çevresi (özel sayı 4): 62-65 (ilk yayınlanma Sanat Çevresi 1983 / 53).

Silivrili, Kerim. 2003. Akademi'ye Tanıklık: 3 (Güzel Sanatlar Akademisi'ne Bakıșlar: Dekoratif Sanatlar) içinde, A. Ö. Gezgin (ed.). İstanbul: Bağlam Yayınları, 69-130.

Sönmez, Zeki (yay. haz.). 1983. Güzel Sanatlar Eğitiminde 100 Yıl. İstanbul: M.S.Ü. Yayını. No:3.

Şekeroğlu, Sami. 2003. Mimar Sinan Üniversitesi SinemaTV Merkezi. Sanat Çevresi (özel sayı 4): 108 115

Tanyeli, Uğur (ed.). 1990. Türk Mimarisinin Mihenk Taşı: Sedad Hakkı Eldem. Arredomento Dekorasyon Sedad Eldem Özel Sayısı, Eylül 1990.

Tarcan, Ercüment. 2003. Akademi'ye Tanıklık: 2 (Güzel Sanatlar Akademisi'ne Bakışlar: Mimarlık) içinde, A. Ö. Gezgin (ed.). İstanbul: Bağlam Yayınlar1, 31-72.

Tuğlacı, Pars. 1981. Osmanlı Mimarlığında Batılılaşma Dönemi ve Balyan Ailesi. İstanbul: İnkılâp ve Aka Yayınları.

Türkmen, Muhlis. 1993, Anılarda Akademi ve Mimari Üzer ine Not ve Cizgiler. Sanat Cevresi 175: 16-20.

Türkmen, Muhlis. 1999. Tasarım ve Kenarda Kalan Düşünceler. Tasarım+Kuram M.S.Ü. Mimarlık Fakültesi Dergisi. Mayıs 1999 (1): 1-8

Esad Suher ile görüsme. 28.10.2011, M.S.G.S.Ü. M.F. Çevre Tasarımı Bilim Dalı odası.

Mete Ünal ile görüșme, 22.11.2011, M.S.G.S.Ü. M.F Bina Bilgisi Bilim Dalı odası.

Ataman Demir ile görüşme, 04.11.2011, M.S.G.S.Ü. M.F Bina Bilgisi Bilim Dalı odası. 